\title{
Metabolic flexibility of aerobic methanotrophs under anoxic conditions in Arctic lake sediments
}

\author{
Ruo He (iD) ${ }^{1,2,3 凶}$, Jing Wang ${ }^{2}$, John W. Pohlman (iD) ${ }^{4}$, Zhongjun Jia (D) ${ }^{5}$, Yi-Xuan Chu ${ }^{2}$, Matthew J. Wooller (iD) ${ }^{6,7}$ and Mary Beth Leigh (iD ${ }^{3 凶}$ \\ (c) The Author(s), under exclusive licence to International Society for Microbial Ecology 2021
}

\begin{abstract}
Methane $\left(\mathrm{CH}_{4}\right)$ emissions from Arctic lakes are a large and growing source of greenhouse gas to the atmosphere with critical implications for global climate. Because Arctic lakes are ice covered for much of the year, understanding the metabolic flexibility of methanotrophs under anoxic conditions would aid in characterizing the mechanisms responsible for limiting $\mathrm{CH}_{4}$ emissions from high-latitude regions. Using sediments from an active $\mathrm{CH}_{4}$ seep in Lake Qalluuraq, Alaska, we conducted DNA-based stable isotope probing (SIP) in anoxic mesocosms and found that aerobic Gammaproteobacterial methanotrophs dominated in assimilating $\mathrm{CH}_{4}$. Aerobic methanotrophs were also detected down to $70 \mathrm{~cm}$ deep in sediments at the seep site, where anoxic conditions persist. Metagenomic analyses of the heavy DNA from ${ }^{13} \mathrm{CH}_{4}$-SIP incubations showed that these aerobic methanotrophs had the capacity to generate intermediates such as methanol, formaldehyde, and formate from $\mathrm{CH}_{4}$ oxidation and to oxidize formaldehyde in the tetrahydromethanopterin $\left(\mathrm{H}_{4} \mathrm{MPT}\right)$-dependent pathway under anoxic conditions. The high levels of Fe present in sediments, combined with Fe and $\mathrm{CH}_{4}$ profiles in the persistent $\mathrm{CH}_{4}$ seep site, suggested that oxidation of $\mathrm{CH}_{4}$, or, more specifically, its intermediates such as methanol and formaldehyde might be coupled to iron reduction. Aerobic methanotrophs also possessed genes associated with nitrogen and hydrogen metabolism, which might provide potentially alternative energy conservation options under anoxic conditions. These results expand the known metabolic spectrum of aerobic methanotrophs under anoxic conditions and necessitate the re-assessment of the mechanisms underlying $\mathrm{CH}_{4}$ oxidation in the Arctic, especially under lakes that experience extended $\mathrm{O}_{2}$ limitations during ice cover.
\end{abstract}

The ISME Journal (2022) 16:78-90; https://doi.org/10.1038/s41396-021-01049-y

\section{INTRODUCTION}

Lakes at latitudes $>50^{\circ} \mathrm{N}$ emit an estimated $18.8 \mathrm{Tg}$ methane $\left(\mathrm{CH}_{4}\right)$ per year directly into the atmosphere [1], which is more than twice that from the oceans $[2,3]$. Biological aerobic $\mathrm{CH}_{4}$ oxidation has been considered an important pathway to mitigate $\mathrm{CH}_{4}$ emission from Arctic lakes, even at low temperatures (down to at least $4{ }^{\circ} \mathrm{C}$ ) [4]. Arctic lakes are usually ice-covered for as much as 9 months from September through the following June [5]. When ice cover forms on Arctic lakes, $\mathrm{O}_{2}$ concentration declines, with shallow lakes eventually becoming hypoxic (dissolved oxygen $<1 \%$ equilibrium solubility). Dissolved $\mathrm{CH}_{4}$ accumulates in Arctic lake waters as $\mathrm{O}_{2}$ dissipates [5]. Mechanisms and rates of $\mathrm{CH}_{4}$ oxidation under these hypoxic and anoxic conditions in Arctic lakes are not well documented, despite the fact that these low $\mathrm{O}_{2}$ conditions persist for the majority of the year and any oxidation that may occur could impact the otherwise large net flux of $\mathrm{CH}_{4}[6,7]$.

$\mathrm{CH}_{4}$ oxidation under anoxic conditions plays an important role in controlling $\mathrm{CH}_{4}$ input to the atmosphere in various environments. In marine sediments, anaerobic oxidation of $\mathrm{CH}_{4}$ (AOM) generally occurs in the niches where $\mathrm{CH}_{4}$ and sulfate overlap [8]. However, nitrate, nitrite, iron III $\left(\mathrm{Fe}^{3+}\right)$, and manganese IV $\left(\mathrm{Mn}^{4+}\right)$ can also serve as electron acceptors for $\mathrm{CH}_{4}$ oxidation in the absence of $\mathrm{O}_{2}$ under anoxic conditions, especially in freshwater environments where sulfate is less abundant than in seawater $[9,10]$. Such reactions provide a greater free energy yield than sulfate-dependent $\mathrm{CH}_{4}$ oxidation under standard conditions [9]. Decomposition products such as humic substances also can potentially act as an electron shuttle for AOM with metallic oxides as terminal electron acceptor in organic carbon-rich environments [11].

AOM is thought to be performed mainly by anaerobic methaneoxidizing archaea (ANME), which are generally divided into three archaeal clades, including ANME-1 (with subgroups $a$ and b) distantly related to Methanomicrobiales and Methanosarcinales, ANME-2 (with subgroups $a, b$, and c) associated with the order Methanosarcinales, and ANME-3, which is more related to Methanococcoides spp. [8, 9]. ANME are commonly associated with sulfate-reducing bacteria (SRB) of the Desulfosarcina/Desulfococcus branch of Deltaproteobacteria. However, some ANME-2 also have been found to independently function in monospecific aggregations or as single filaments [12, 13]. "Omic" and single cell visualization approaches showed that archaeal family

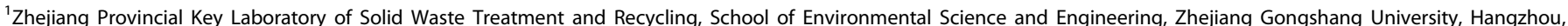

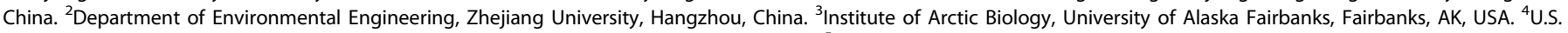

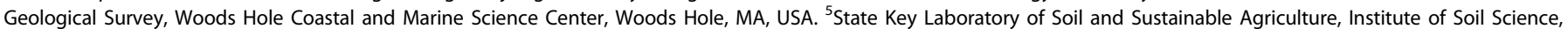

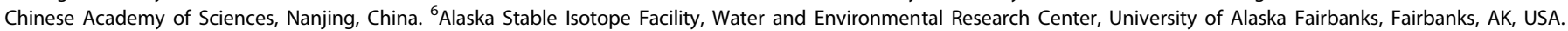

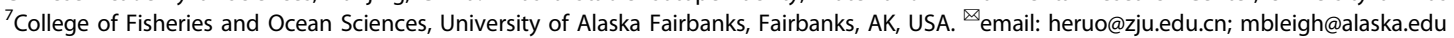


Methanoperedenaceae (formerly known as ANME-2d) can independently oxidize $\mathrm{CH}_{4}$ using nitrate as the terminal electron acceptor [14]. AOM coupled to the reduction of $\mathrm{Fe}^{3+}$ and $\mathrm{Mn}^{4+}$ was first found to be associated with the groups Bacteriodes, Proteobacteria (including Geobacter), Acidobacteria, and Verrucomicrobia, although direct evidence was lacking [15]. Recently, members of Methanoperedenaceae such as "Candidatus Methanoperedens ferrireducens" and "Candidatus Methanoperedens sp. MPEBLZ" have been reported to be capable of coupling AOM to the reduction of $\mathrm{Fe}^{3+}$ and $\mathrm{Mn}^{4+}$ [15-17]. And, "Candidatus Methylomirabilis oxyfera", a member of the Methylomirabilota phylum (NC10), has been found to bypass the denitrification intermediate nitrous oxide by converting nitric oxide to dinitrogen and $\mathrm{O}_{2}$ under anoxic conditions, with $\mathrm{O}_{2}$ being utilized to aerobically oxidize $\mathrm{CH}_{4}$ [18].

Aerobic methanotrophs are curiously abundant in anoxic habitats [19-21], where they are generally thought to be dormant, existing as cysts or exospores, since $\mathrm{O}_{2}$ is required for catalyzing the conversion of methane to methanol by either soluble or particulate methane monooxygenase (pMMO) [21]. Recently, however, aerobic methanotrophs have been reported to actively oxidize $\mathrm{CH}_{4}$ under anoxic conditions. For example, Oswald et al. [22] found that Gammaproteobacterial methanotrophs dominated in the oxic/anoxic boundary and anoxic hypolimnion of Lake Zug and $\mathrm{CH}_{4}$ oxidation was stimulated by addition of iron and manganese oxides under anoxic conditions. In sub-Arctic lake sediment, Martinez-Cruz et al. [19]. reported assimilation of $\mathrm{CH}_{4}{ }^{-}$ derived carbon by aerobic methanotrophs, methylotrophs, and iron reducers. Cabrol et al. [23]. reported that the aerobic methanotrophs Methylomonadaceae (mainly Methylobacter) and Crenothrix actively oxidized $\mathrm{CH}_{4}$ in the anoxic water of Northwestern Siberian lakes in association with denitrifiers and ironcycling partners. Milucka et al. [24]. found that aerobic $\mathrm{CH}_{4}$ oxidation coupled to oxygenic photosynthesis within the photic anoxic chemocline of Lake Cadagno. Additionally, aerobic methanotrophs have the metabolic flexibility to perform processes such as fermentation or $\mathrm{CH}_{4}$ oxidation coupled to nitrate reduction to mitigate $\mathrm{O}_{2}$ starvation $[25,26]$.

Here we aimed to reveal the identities and metabolic pathways potentially utilized by methanotrophs active under anoxic conditions in sediments obtained from an active $\mathrm{CH}_{4}$ seep in Lake Qalluuraq, an Arctic lake located near Atqasuk on the north slope of the Brooks Range in Alaska. We applied molecular methodologies including DNA-based stable isotope probing (SIP) coupled with shotgun metagenomics and amplicon sequencing of bacterial and archaeal 16S rRNA genes and quantitative real-time PCR (qPCR) with monitoring of geochemical parameters such as dissolved $\mathrm{CH}_{4}$ concentration and $\mathrm{HCl}$-extractable Fe content. Our findings revealed that aerobic methanotrophs have the ability to be active in anoxic environments where they have typically been presumed to be inactive and that they might couple the oxidation of $\mathrm{CH}_{4}$ or its intermediates to the reduction of iron, which is abundant in the sediments of this lake. These observations have important implications for understanding the fate of $\mathrm{CH}_{4}$ in the anoxic sediments of Arctic lakes and during the extended icecovered season when more extensive lake anoxia develops.

\section{MATERIALS AND METHODS}

\section{Sampling and physio-chemical analysis}

Lake Qalluuraq, a tundra lake with a persistent $\mathrm{CH}_{4}$ seep located near Atqasuk on the North Slope of the Brooks Range in Alaska, was sampled in May (ice-covered) and July (open-water), 2009. Ice thickness above the seep was $\sim 50 \mathrm{~cm}$ in May. Sediments from the seep site $\left(70^{\circ} 22.669^{\prime} \mathrm{N}, 157^{\circ}\right.$ $20.925^{\prime} \mathrm{W}$ ) were collected using coring tubes $(7 \mathrm{~cm}$ diameter) and were subsampled within $12 \mathrm{~h}$ of collection. The sediment subsamples were immediately placed into sealed plastic zipper freezer bags with air removed from the headspace. Samples were homogenized in the bag and subsamples were frozen at $-80^{\circ} \mathrm{C}$ for direct molecular studies and $\mathrm{Fe}$ content analysis. The remaining sediment was stored at $4{ }^{\circ} \mathrm{C}$ and was used to conduct the SIP experiment immediately upon our return to the lab at the University of Alaska Fairbanks. Dissolved $\mathrm{CH}_{4}$ concentrations in the sediment pore fluids were analyzed as described previously by $\mathrm{He}$ et al. [19]. Elemental and mineralogical composition of sediments was estimated by X-ray diffraction analysis [27].

Since iron redox cycling exerts a wide-ranging influence on the biogeochemistry of sedimentary environments, we analyzed the $\mathrm{HCl}$ extractable Fe content including iron (II) $\left(\mathrm{Fe}^{2+}\right), \mathrm{Fe}^{3+}$, and total Fe [28]. In brief, $\sim 10 \mathrm{~g}$ (wet weight) sediment subsample (stored frozen at $-80^{\circ} \mathrm{C}$ for 1 year after sampling) was acidified with $\mathrm{HCl}$ to $\mathrm{pH}<1$ and freeze-dried at $-40{ }^{\circ} \mathrm{C}$ in the laboratory. Then, $\sim 1 \mathrm{~g}$ freeze-dried sediment was taken for measurement of $\mathrm{Fe}^{2+}$ and total $\mathrm{Fe}$ content in an anaerobic chamber. Each sample was measured in triplicate. The $\mathrm{Fe}^{2+}$ and total Fe content of the sediments were determined by the method described previously [29]. The resulting $\mathrm{HCl}$-extractable $\mathrm{Fe}^{2+}$ to total $\mathrm{Fe}$ ratio of $90 \%$ indicated that $\mathrm{Fe}$ oxidation during sample storage was negligible.

\section{SIP microcosms}

SIP microcosms were prepared by adding $\sim 10 \mathrm{~g}$ (wet weight) of $25-50-\mathrm{cm}-$ depth sediment to sterile $60-\mathrm{ml}$ glass serum vials in an anaerobic chamber, where the gas composition was $1-2 \% \mathrm{H}_{2}$ and $98-99 \% \mathrm{~N}_{2}$. Five different treatments were established by adding combinations of 2bromoethanesulfonic acid (BES, a methanogen-specific inhibitor), sodium molybdate (SM, a specific inhibitor for sulfate reduction [30]), and $\mathrm{Na}_{2} \mathrm{SO}_{4}$ (EA, as a supplementary electron acceptor), and then were purged with ultra-high-purity (UHP) $\mathrm{N}_{2}(99.999 \%)$ to remove $\mathrm{O}_{2}$. The five treatments were amended as follows, with treatment codes in parentheses: (1) BES and $\mathrm{SM}(\mathrm{BES}+\mathrm{SM})$; (2) BES (BES); (3) SM (SM); (4) EA (EA); and (5) unamended with $\mathrm{BES}, \mathrm{SM}$, or EA as control (None). Autoclaved $\mathrm{O}_{2}$-free water was supplied at a total volume of $2 \mathrm{ml}$ (including BES, SM, EA, and autoclaved water) for each treatment. The final concentrations of BES, SM, and $\mathrm{Na}_{2} \mathrm{SO}_{4}$ were 10,5 , and $3 \mathrm{mM}$, respectively, in the treatments. Resazurin was added to a final concentration of $0.001 \%$ in the microcosms to monitor for the presence of $\mathrm{O}_{2}$. The serum vials were flushed with UHP N $\mathrm{N}_{2}$ and sealed with butyl rubber stoppers (Chemglass Life Sciences) in the anaerobic chamber containing $1-2 \% \mathrm{H}_{2}$ and $98-99 \% \mathrm{~N}_{2}$, and pre-incubated for a month to exhaust any $\mathrm{O}_{2}$ potentially carried over from the original sediments. Then, the serum vials were flushed with UHP $\mathrm{N}_{2}$ and amended with BES, SM, $\mathrm{Na}_{2} \mathrm{SO}_{4}$, autoclaved water, and resazurin and sealed with butyl rubber stoppers in the anaerobic chamber. The headspace of the serum vials was $\sim 50 \mathrm{ml} .{ }^{13} \mathrm{CH}_{4}$ (99 atom $\%{ }^{13} \mathrm{C}$, Sigma-Aldrich, USA) or $\mathrm{CH}_{4}$ (99.5\% purity, as unlabeled control) was injected to obtain a headspace concentration of $5 \%$ $\mathrm{CH}_{4}(\mathrm{v} / \mathrm{v})$, a concentration chosen to represent the extensive $\mathrm{CH}_{4}$ accumulation associated with the active seep under ice-covered conditions. The serum vials were placed inside a cardboard box and incubated on a rotary platform shaker $(100 \mathrm{rpm})$ in a cold room held at $10^{\circ} \mathrm{C}$. The cold room was not illuminated other than by low-level incidental light entering through a small $\sim 10 \mathrm{~cm}$ by $30 \mathrm{~cm}$ glass observation window in the door during the pre-incubation and SIP experiment. Mesocosms experienced brief indoor light exposures during headspace gas sampling or exchange on the lab bench. All treatments were performed in triplicate.

Headspace gas samples $(50 \mu \mathrm{l})$ were withdrawn from the microcosms at 20-d intervals using a syringe flushed with UHP $\mathrm{N}_{2}$ three times to remove trace $\mathrm{O}_{2}$ before drawing the samples. The $\mathrm{CH}_{4}$ concentration was quantified as described previously [20]. $\mathrm{CH}_{4}$ oxidation potential was assessed from the zero-order decrease in $\mathrm{CH}_{4}$ concentration in the headspace of the serum vials during the incubation period with differences analyzed statistically by ANOVA (one-way analysis of variance) using SPSS 19.0. Relatively stable $\delta^{13} \mathrm{C}_{\text {of }} \mathrm{CH}_{4}$ in the headspace indicated minimal $\mathrm{CH}_{4}$ production in the vials. The serum vials were flushed with UHP $\mathrm{N}_{2}$ and sealed with butyl rubber stoppers in the anaerobic chamber and recharged with ${ }^{13} \mathrm{CH}_{4}$ or $\mathrm{CH}_{4}$ every 40 or 80 days to remove ${ }^{13} \mathrm{CO}_{2}$ and reduce crossfeeding. The incubation was continued in the same manner until 240 days of incubation, when $\mathrm{CH}_{4}$ had been injected in the vials five times as described above. At the end of the incubation, the sediment samples were harvested and frozen immediately at $-80^{\circ} \mathrm{C}$.

\section{Quantification of ${ }^{13} \mathrm{C}$ and ${ }^{18} \mathrm{O}$ in headspace $\mathrm{CO}_{2}$}

In order to monitor the conversion of ${ }^{13} \mathrm{CH}_{4}$ and $\mathrm{H}_{2}{ }^{18} \mathrm{O}$ into $\mathrm{CO}_{2}$, we quantified the ${ }^{13} \mathrm{C}$ and ${ }^{18} \mathrm{O}$ in headspace $\mathrm{CO}_{2}$. Approximately $10 \mathrm{~g}$ (wet weight) of original sediment collected from the $25-50-\mathrm{cm}$ depth range was added to sterile $60-\mathrm{ml}$ glass serum vials and incubated on a shaker as 
described in SIP microcosms. Considering the low $\mathrm{CH}_{4}$ oxidation activity of sediment in the first stage, ${ }^{12} \mathrm{CH}_{4}$ was injected instead of ${ }^{13} \mathrm{CH}_{4}$ in the first 40 days. Then the serum vials were flushed with $\mathrm{UHP} \mathrm{N}_{2}$, amended with 10 $\mu \mathrm{l} \mathrm{H}_{2}^{18} \mathrm{O}$, and sealed with butyl rubber stoppers in the anaerobic chamber. ${ }^{13} \mathrm{CH}_{4}$ was injected into the serum vials to the initial concentrations of $5 \%$ $(\mathrm{v} / \mathrm{v})$. All serum vials were incubated as described above. One-milliliter headspace gas samples were periodically collected to measure the $\delta^{18} \mathrm{O}$ and $\delta^{13} \mathrm{C}$ values of $\mathrm{CO}_{2}$ at the Alaska Stable Isotope Facility (University of Alaska Fairbanks) [31].

\section{DNA extraction, gradient centrifugation, qPCR, and T-RFLP analysis}

DNA was extracted from 3 to $4 \mathrm{~g}$ (wet weight) of the sediment samples using the Bio101 Fast DNA Spin Kit for soil (MP Biomedicals, Solon, OH, USA). For SIP, equilibrium (isopycnic) density gradient centrifugation and fractionation were performed as described previously [32]. The relative abundance of bacterial DNA in gradient fractions was determined by qPCR to identify the heavy $\left({ }^{13} \mathrm{C}\right.$-labeled) DNA as described by Leigh et al. [33]. The fractions of buoyant density (BD) ranging from $1.620 \mathrm{~g} \mathrm{ml}^{-1}$ to $1.642 \mathrm{~g} \mathrm{ml}^{-1}$ and $1.584 \mathrm{~g} \mathrm{ml}^{-1}$ to $1.608 \mathrm{~g} \mathrm{ml}^{-1}$ were combined to constitute compiled 'heavy fractions' and 'light fractions', respectively (Supplementary Figs. S1 and S2).

Total community DNA was extracted from the original sediment core samples collected in July in $5-\mathrm{cm}$ intervals spanning $0-70 \mathrm{~cm}$ core depth. The populations of bacteria, archaea, and methanotrophs in the original sediments was estimated by $\mathrm{QPCR}$ targeting bacterial and archaeal $16 \mathrm{~S}$ rRNA genes and pmoA with the primer sets Bac331F/Bac797R, Ar349F/ Ar806R, and $A 189 \mathrm{~F} / \mathrm{mb} 661 \mathrm{R}$, respectively [34]. The primer sets Bac331F/ Bac797R, Ar349F/Ar806R have coverage of $68.4 \%$ and $71.6 \%$ of bacteria and archaea in the SILVA rRNA database, respectively. Since all known methanotrophs have particulate MMO (pMMO) except for Methylocella [35] and Methyloferula [36], the gene pmoA encoding pMMO has been widely used to study the taxonomic identity and community of methanotrophs in the environment [37]. The DNA from the original sediments were used as templates for T-RFLP analysis as described previously $[32,38,39]$. The peak areas within each T-RFLP were converted to proportional peak areas and then were used for principal component analysis (PCA) to screen for community structural patterns prior to more indepth molecular analyses [38].

\section{Analyses of bacterial and archaeal 16S rRNA genes}

PCR targeting bacterial and archaeal 16S rRNA genes was performed on the following sample types: (1) total community DNA from the sediments homogenized from 25 to $50 \mathrm{~cm}$ deep (initial sediment used for incubations), (2) the heavy and light fractions from the ${ }^{13} \mathrm{CH}_{4}$-incubated samples unamended with inhibitors or electron acceptors, and (3) the heavy fractions from the ${ }^{12} \mathrm{CH}_{4}$-incubated samples (unlabeled controls, unamended with inhibitors or electron acceptors). The primer sets $27 \mathrm{~F} /$ 1392R and Ar309F/Ar915R were used to amplify bacterial and archaeal 16S rRNA genes. The PCR amplification and cloning were performed in three replicates as described previously [32]. A total of 192 and 96 clones (averaging 64 and 32 clones from each replicate) were selected randomly from the heavy and light fractions from the ${ }^{13} \mathrm{CH}_{4}$-incubated samples, respectively. All 21 clones obtained from the heavy fractions of unlabeled controls were sequenced and analyzed using previously described methods [32]. The high-quality sequences were dereplicated with the CAP3 sequence assembly program with $97 \%$ similarity [40]. The phylogenetic affiliations of bacterial sequences were classified using the Ribosomal Database Project (RDP) (http://rdp.cme.msu.edu). Phylogenetic trees of archaeal clone sequences were constructed using MEGA $X$ 10.1 software employing the maximum-likelihood method based on Kimura 2-parameter model as described previously [32].

\section{Metagenomic analysis}

Total DNA was extracted from the sediment cores $(25-50 \mathrm{~cm}$ depth, homogenized) and the heavy DNA fractions from the ${ }^{13} \mathrm{CH}_{4}$-incubated samples (unamended with electron acceptors or inhibitors) for shotgun metagenomic analysis. Since the quantity of DNA in SIP fractions was low, the heavy fractions from all the samples were merged into one sample. Genomic DNA was fragmented using sonication and subjected to shotgun metagenomic analysis by the Beijing Genomics Institute (BGl, China). Paired-end fragment libraries with the insert size of $350 \mathrm{bp}$ were constructed. Adapter-appended fragments were sequenced on HiSeq
2500 platform (Illumina). Raw sequencing reads were filtered to obtain high-quality data (quality-filtered data) for subsequent analysis as described previously [41]. A percentage of $95.41-95.65 \%$ reads were filtered and then assembled de novo with SOAP denovo2 [42] and Rabbit [43]. MetaGeneMark (version 2.10, default parameters) was used to predict open reading frames based on assembly results [44, 45]. Genes from different samples were combined together and clustered using CD-HIT (version 4.6.1) [46] to remove redundant sequences (sequence identity threshold $95 \%$ and alignment coverage threshold 90\%) [45]. The relative abundance of gene cluster representatives in each sample was calculated using the formula below as described previously [47].

$$
G_{i}=\frac{\frac{P_{i}}{L_{i}}}{\sum_{j=1}^{n} \frac{P_{j}}{L_{j}}}
$$

Where $G_{i}$ is the relative abundance of gene $i$ in the sample, $P_{i}$ is the number of reads mapped to gene $i, L_{i}$ is the length of gene $i$, and $n$ is the gene number in the assembled metagenomic data.

The gene catalogs were aligned against the eggNOG database (201510), CAZy database (2017-09), COG database (2014-11), Swiss-prot database (2017-07), the KEGG database (89.1), and CARD database (4.0) using DIAMOND with an e-value cutoff of $10^{-5}[45,46]$ to search the protein sequences. Ambiguously aligned sequencing reads were then reassigned to genes using Pathoscope v1.0, which uses a Bayesian framework to examine sequence of each read and mapping quality within the context of a global reassignment [48]. Taxonomic assignment of the predicted genes was carried out using MEGAN (version 5.3) and subjected to BLASTX analysis using the NCBI-nr database (2016-09) as described previously [49]. The relative abundance of members of each taxonomic level was approximated by calculating the number of the gene reads affiliated with the taxonomic level to the total number of assembled reads per metagenome with an average assembly length of $13,697,259 \mathrm{bp}$ and an average mapping rates of $31.05 \%$.

Clone sequences and metagenomic data sets in this study have been submitted to the GenBank database and the NCBI Short Read Archive under accession numbers MN788533-MN788604 and SRP234857 (BioSample SAMN13483815 and SAMN13483816 for the heavy DNA, and BioSample SAMN13483815 and SAMN13483816 for the total DNA of the original sediment), respectively.

\section{RESULTS}

\section{Biochemical characterization of seep sediments}

In May (ice-covered conditions), dissolved $\mathrm{CH}_{4}$ levels in porewater were similar along the core depth ranging from 136 to $\sim 355 \mu \mathrm{M}$ (Fig. 1). However, in July (ice-free), porewater dissolved $\mathrm{CH}_{4}$ concentrations were low $(<15 \mu \mathrm{M})$ in the upper sediments $(0-10$ $\mathrm{cm})$, and, as the sediment depth increased, dissolved $\mathrm{CH}_{4}$ concentration increased and reached a maximum of $1334 \mu \mathrm{M}$ at a depth of $25 \mathrm{~cm}$ in the sediment, which was 4-fold higher than observed at the same depth in May.

The content of $\mathrm{HCl}$-extractable total Fe was $2526 \mathrm{mg} \mathrm{kg}^{-1}$ dry weight (hereafter presented as $\mathrm{mg} \mathrm{kg}^{-1}$ ) at the sediment-water interface, and increased to $14,846 \mathrm{mg} \mathrm{kg}^{-1}$ at the $10-15 \mathrm{~cm}$ depths, and then showed an overall decreasing trend with depth in May (Fig. 1D). The content of $\mathrm{HCl}$-extractable $\mathrm{Fe}^{2+}$ showed a similar curve to the total Fe with higher values of $8326-14,698 \mathrm{mg} \mathrm{kg}^{-1}$ at the depths between 5 and $15 \mathrm{~cm}$. The percent of $\mathrm{HCl}$-extractable $\mathrm{Fe}^{2+}$ to total Fe content was $77 \%$ at the sediment-water interface, increased to $95 \%$ at the depths between 10 and $15 \mathrm{~cm}$, and averaged $94 \%$ for the remaining depths in May. The $\mathrm{HCl}$-extractable total Fe content was lower overall in the upper sediments in July than in May (Fig. 1E). The $\mathrm{HCl}$-extractable total Fe content in the sediments in July showed an increasing trend from 10 to $60 \mathrm{~cm}$ with a drop at the depth of $45-50 \mathrm{~cm}$ in the sediments. In July, the percent of $\mathrm{HCl}$ extractable $\mathrm{Fe}^{2+}$ to total $\mathrm{Fe}$ was $29 \%$ at the sediment-water interface, increased with depth to $67-68 \%$ at the depth of $25-30 \mathrm{~cm}$, and then kept stable with a range of $73-78 \%$ for the remaining depths. X-ray diffraction analysis showed that $\mathrm{Fe}_{3} \mathrm{O}_{4}$ and $\mathrm{FeS}_{2}$ were the main forms of $\mathrm{Fe}$, accounting for $1.65 \%$ and $0.16 \%$, respectively, in the sediments in July, which was higher than the $\mathrm{HCl}$-extractable 

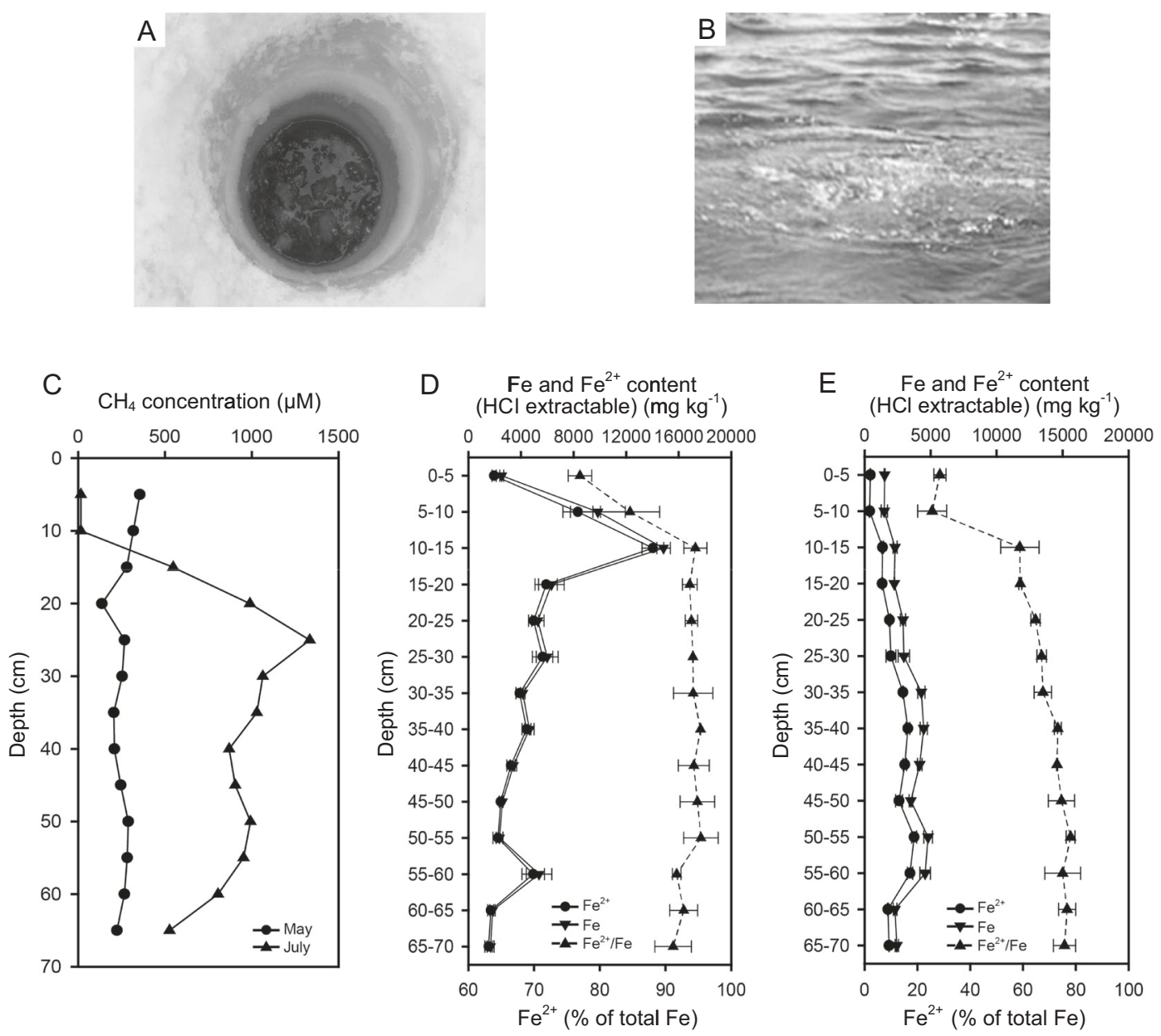

Fig. 1 Sediment depth profiles for dissolved $\mathrm{CH}_{4}$ concentration and $\mathrm{HCl}$-extractable iron contents in the seep site $\left(70^{\circ} 22.669^{\prime} \mathrm{N}, 157^{\circ}\right.$ 20.925 $\mathbf{W}$ ) in Lake Qalluuraq near Atqasuk on the North Slope of the Brooks Range in Alaska. Images of $\mathrm{CH}_{4}$ ebullition at the water surface above the persistent seep location in May (A) and July (B), 2009. Dissolved $\mathrm{CH}_{4}$ concentration (C), $\mathrm{HCl}$-extractable total Fe, Fe ${ }^{2+}$ and the percent of $\mathrm{Fe}^{2+}$ to total Fe of the seep-associated sediments $(n=3)$ collected in ice-covered May (D) and ice-free July 2009 (E). Error bars indicate standard deviation.

Fe, likely owing to the low extraction of $\mathrm{Fe}_{3} \mathrm{O}_{4}$ (Supplementary Table S1).

The bacterial abundance was highest in the upper sediments $(0-15 \mathrm{~cm})$ in July with $2.3 \times 10^{8}$ to $5.2 \times 10^{8}$ copies $\mathrm{g}^{-1}$ (Fig. 2A). As the sediment depth increased from 20 to $70 \mathrm{~cm}$, the bacterial abundance gradually decreased from $6 \times 10^{6}$ to $1.3 \times 10^{6}$ copies $\mathrm{g}^{-1}$. Archaea and aerobic methanotrophs were detected along the entire $70-\mathrm{cm}$ sediment core. The maximum abundance of archaea and aerobic methanotrophs were detected at $10-15 \mathrm{~cm}$ with $2.7 \times 10^{6}$ and $3.7 \times 10^{5}$ copies $\mathrm{g}^{-1}$, respectively. The T-RFLP profiles of bacterial 16S rRNA genes from the original $0-70-\mathrm{cm}$ sediment core depth profile formed four groups in ordination space based on their depth ranges $0-10,10-20,20-55$, and $55-70 \mathrm{~cm}$ (Fig. 2B and Supplementary Fig. S3).

\section{$\mathrm{CH}_{4}$ oxidation potential in anoxic SIP microcosms}

Based on the principal component analysis of T-RFLP profiles and our finding that the position of the oxic-anoxic interface was located $15 \mathrm{~cm}$ below the sediment surface based on the same core from the seep site [20], we selected the deeper $25-50 \mathrm{~cm}$ sediment depths as the subject of anoxic SIP experiments. During the SIP microcosm incubation, low $\mathrm{CH}_{4}$ consumption was detected in the first 20 day (Fig. 3A, B). After 20 days, the $\mathrm{CH}_{4}$ consumption increased and varied over time. At the end of the experiment, the total $\mathrm{CH}_{4}$ consumption in the experimental SIP microcosms was $0.028-0.030 \mathrm{mmolg}^{\mathrm{g}}$ wet weight ${ }^{-1}$. The $\mathrm{CH}_{4}$ oxidation potentials of the experimental sediments ranged from 0.126 to $0.136 \mu \mathrm{mol} \mathrm{g}^{-1} \mathrm{~d}^{-1}$ (Fig. 3C). The addition of EA, SM, and/ or $\mathrm{BES}$ did not have a significant effect on the $\mathrm{CH}_{4}$ oxidation potential in any of the treatments $(p>0.587)$.

We supplied ${ }^{13} \mathrm{CH}_{4}$ and $\mathrm{H}_{2}{ }^{18} \mathrm{O}$ to incubations in order to track the carbon and oxygen sources into the headspace $\mathrm{CO}_{2}$. Within the 20-day incubation, the $\delta^{13} \mathrm{C}$ and $\delta^{18} \mathrm{O}$ values of the $\mathrm{CO}_{2}$ in the headspace of serum vials both increased with time (Fig. 3D), suggesting that $\mathrm{CH}_{4}$-derived carbon and $\mathrm{H}_{2} \mathrm{O}$-derived oxygen were converted into $\mathrm{CO}_{2}$.

\section{SIP targeting bacterial 16S rRNA genes}

We conducted bacterial 16S rRNA gene cloning and sequencing to identify bacteria active in assimilating $\mathrm{CH}_{4}$-derived carbon. Three bacterial 16S rRNA gene clone libraries were established, including the heavy $(\mathrm{BH})$ and light (BL) fractions from the ${ }^{13} \mathrm{CH}_{4}$-incubated samples, and the heavy fractions from the ${ }^{12} \mathrm{CH}_{4}$-incubated samples as a control (BC). In the total, 135 bacterial 16S rRNA gene clones were sequenced from the $\mathrm{BH}$ library. Of these, $70.2 \%$ were assigned to Proteobacteria. Within the Proteobacteria, 54.1\% (73 out of 135 clones) were affiliated with Methylobacter, 7.4\% were affiliated with Methylotenera, 3.0\% belonged to the genus Rhodoferax, and others were assigned to Afipia, unclassified Acetobacteaceae, unclassified Alphaproteobacteria, Thiobacillus, Methylophilus, and unclassified Betaproteobacteria (Fig. 4). The genera Gp6 and Gp7 in Actinobacteria were dominant (accounting 
A Gene copy number (Log copies $\mathrm{g}^{-1}$ )
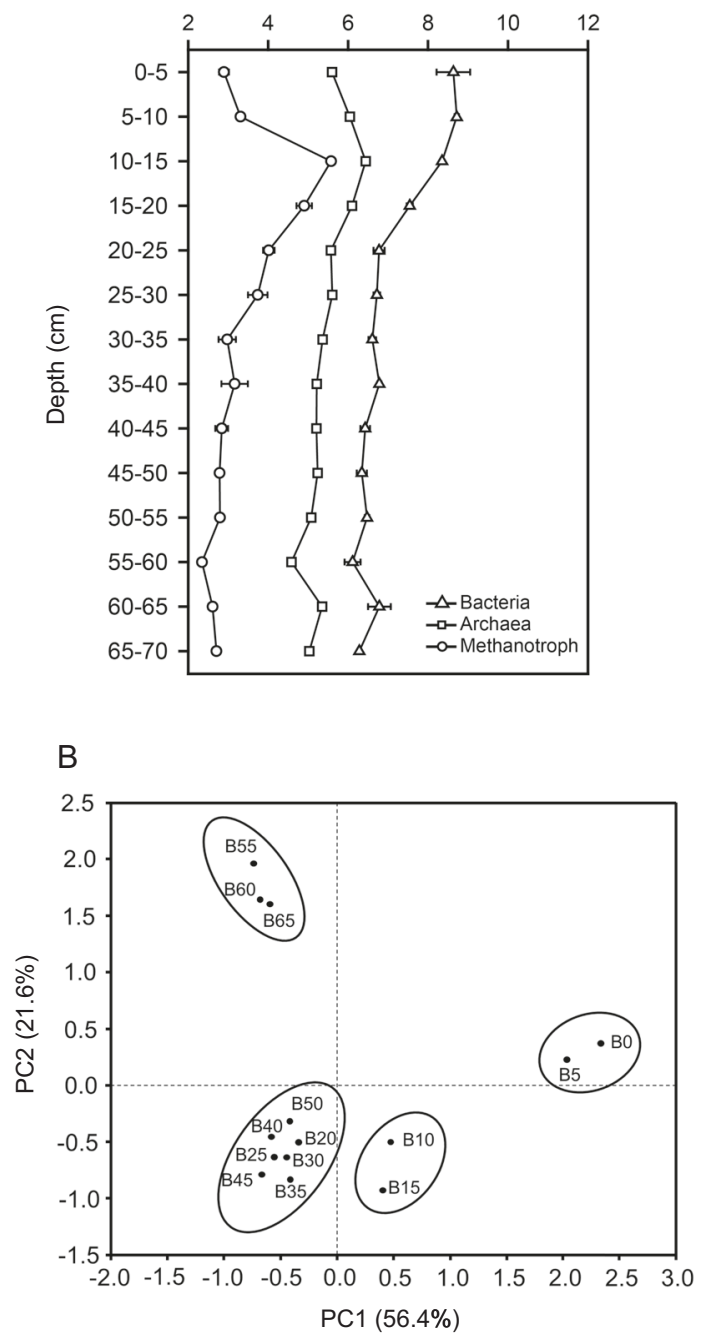

Fig. 2 The microbial diversity in the samples from the sediment cores. The abundance of bacteria, archaea, and methanotrophs estimated using quantitative real-time PCR (qPCR) targeting bacterial and archaeal 16S rRNA genes and pmoA based on the dry weight of sediment $(n=3)(\mathbf{A})$, and principal component analysis of bacterial terminal restriction fragment length polymorphism (TRFLP) profiles of $16 \mathrm{~S}$ rRNA gene amplicons digested with Hhal for DNA from the original sediment of $0-70 \mathrm{~cm}$ at $5 \mathrm{~cm}$ intervals (B), which were collected in ice-free July 2009. The number embedded within the sample name (i.e., B0, B5, B10, etc.) from 0 to 65 indicates the depth of sediment samples (collected at 5-cm intervals) from 05 to $65-70 \mathrm{~cm}$. Error bars indicate standard deviation.

for $22.3 \%$ of the total clone sequences) in the $\mathrm{BH}$ library. Bacteroidetes, Actinobacteria, Verrucomicrobia, Planctomycetes, and unclassified bacteria were also found in the BH library. Only a total of 14 bacterial 16S rRNA clones were obtained for the BC library, possibly due to the low abundance of DNA in the heavy fraction from the control treatment. The genera Rhodoferax and Gp6 detected in the BH library were also present in the BC library. Of the 83 bacterial 16S rRNA clones sequenced from the BL library, $65.9 \%$ were assigned to Proteobacteria. The genera Rhodoferax and Methylobacter were both found in the $\mathrm{BH}$ and $\mathrm{BL}$ libraries.

\section{SIP targeting archaeal 16S rRNA genes}

We chose the primer set Ar309F/Ar915R to amplify archaeal 165 rRNA genes for sequencing. All 71 archaeal 16S rRNA gene sequences obtained from the heavy fractions from the labeled DNA $(\mathrm{CH})$ library belonged to the same operational taxonomic unit
(OTU) (assigned by CAP3 sequence assembly program with $97 \%$ similarity), and had a $99 \%$ similarity to freshwater sediment clone Cad24-73 (AM851080). This clone was previously detected in sediments of Lake Cadagno and was affiliated with the AOMassociated archaeal (AAA) clade of Euryarchaeota [50] (Fig. 5). Of the 58 sequences from the heavy fraction of the unlabeled DNA (CO) library, unclassified Thermoprotei and unclassified Methanosarcinales were dominant and others were assigned to Methanosaeta, unclassified Euryarchaeota and unclassified Methanomicrobia. Of the 85 archaeal 16S rRNA genes sequenced from the light fractions of the labeled DNA (CL) library, 50.6\% were assigned to unclassified Methanosarcinales, $22.4 \%$ belonged to unclassified Thermoprotei, $16.5 \%$ to Methanobacterium, and $8.2 \%$ to Methanosaeta.

\section{Taxonomic profiling of the metagenomes}

We performed shotgun metagenomic sequencing for the heavy DNA from the ${ }^{13} \mathrm{CH}_{4}$-incubated sediment and the total DNA from the original sediment. A non-redundant catalog of 32,222 genes was constructed with an average $4.72 \mathrm{Gbp}$ clean data. Taxonomic assignment showed that Proteobacteria, Cyanobacteria, Bacteroidetes, Acidobacteria, Actinobacteria, and Firmicutes predominated in the heavy $\left({ }^{13} \mathrm{C}\right.$-labeled) DNA and the original sediment, accounting for $64.3-66.4 \%$ of the taxonomically assigned reads (Fig. 6). In the heavy DNA, Proteobacteria was the dominant phylum, while Cyanobacteria was the predominant microorganism in the original sediment.

In the heavy DNA from the ${ }^{13} \mathrm{CH}_{4}$-incubated SIP sediment (Fig. 6C), sequences affiliated with genera containing known Gammaproteobacterial methanotrophs were detected, including Methylobacter, Methylocaldum, Methylococcus, Methylomarinum, Methylomicrobium, Methylomonas, Methylosarcina, and Methylovulum, accounting for $46.0 \%$ of the taxonomically assigned reads. Among them, Methylobacter (27.0\%) was the most abundant Gammaproteobacterial methanotroph. With the extended incubation time (240 days), $\mathrm{CH}_{4}$-derived carbon could have flowed into more microorganisms by crossing-feeding processes, such as through formaldehyde secretion, $\mathrm{CO}_{2}$ emission, or decay of methanotrophic biomass followed by assimilation by other organisms [51]. Among the top 50 genera in assimilating $\mathrm{CH}_{4^{-}}$ derived carbon, 24 genera were related with nitrogen, sulfide, metal (mainly iron), and electron transport such as Desulfovibrio, Methylotenera, Pseudomonas, Geobacter, Rhodoferax, Shewanella, Acidithiobacillus, and Chlorobium with the total relative abundance of 5.9\% (Supplementary Table S2).

Acaryochloris, a member of Cyanobacteria was also among the top 50 genera that assimilated $\mathrm{CH}_{4}$-derived carbon. Cyanobacteria including Pseudanabaena, Scytonema, Nostoc, Leptolyngbya, Oscillatoria, and Gloeocapsa were also listed the 100 genera assimilating $\mathrm{CH}_{4}$-derived carbon. "Candidatus Metylomirabilis oxyfera" was not detected in the heavy DNA.

In the original sediment microbial community, Cyanobacteria was the most abundant phylum. Of the top 50 genera, 42 were affiliated with the phylum Cyanobacteria, accounting for $54.6 \%$ of the taxonomically assigned reads (Fig. 6D). In the top 100 genera, 49 genera were non-Cyanobacterial with the relative abundance of $4.3 \%$ (Fig. $6 \mathrm{E}$ ). Of them, 18 genera were detected in both the heavy DNA and the original sediment and accounted for $2.1 \%$ of the assigned reads. Gammaproteobacterial methanotrophs including Methylobacter, Methylomicrobium, Methylomonas and Methylovulum and Alphaproteobacterial methanotroph Methylosinus were listed in the top 100 genera, accounting for $0.5 \%$ the taxonomically assigned reads.

\section{Genes involved in $\mathrm{CH}_{4}$ oxidation, nitrogen, hydrogen and iron metabolism}

The first step of $\mathrm{CH}_{4}$ oxidation to methanol is catalyzed by MMO. The genes $p m o C, p m o A$, or $p m o B$ annotated as part of the pmo operon encoding PMMO (named pmo genes) was detected in the 

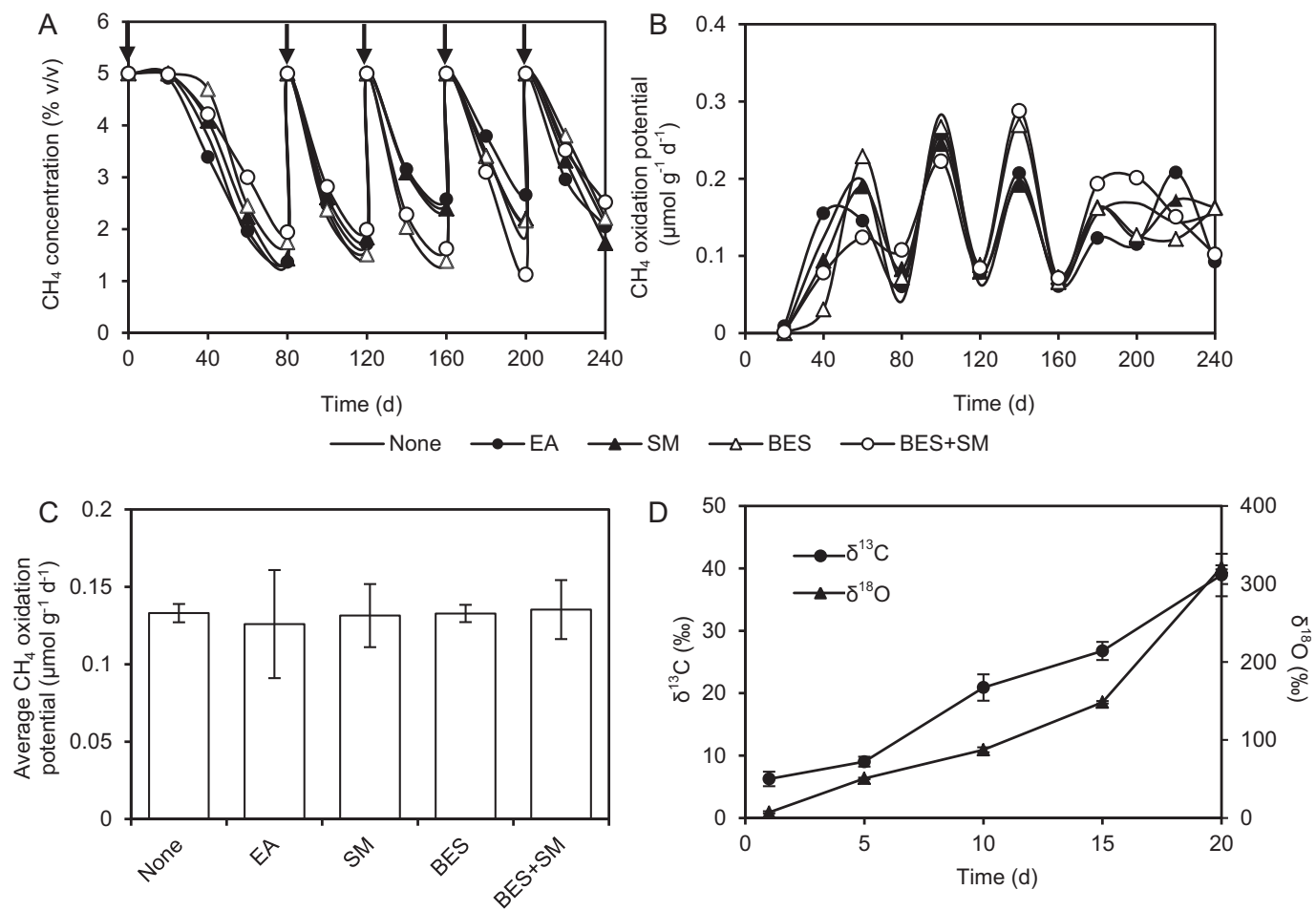

Fig. $3 \mathrm{CH}_{4}$ oxidation activities of sediments in the stable-isotope-probing (SIP) microcosm. The average $\mathrm{CH}_{4}$ concentration in the headspace $(\mathbf{A})$, average $\mathrm{CH}_{4}$ oxidation potential at each time point (B) and average $\mathrm{CH}_{4}$ oxidation potential of each treatment during the whole SIP microcosm incubation $(240 \mathrm{~d})(\mathrm{C})$, and the $\delta^{13} \mathrm{C}$ and $\delta^{18} \mathrm{O}$ of $\mathrm{CO}_{2}$ in the headspace of the serum vials without the addition of inhibitors or electron acceptors (D) $(n=3)$. Five treatments were constructed by adding 2-bromoethanesulfonic acid (BES, a methanogenspecific inhibitor) and/or sodium molybadate ( $\mathrm{SM}$, a specific inhibitor for sulfate reduction), or $\mathrm{Na}_{2} \mathrm{SO}_{4}$ ( $E A$, as a supplementary electron acceptor) into the vials to adjust the final concentrations of $\mathrm{BES}, \mathrm{SM}$ and $\mathrm{Na}_{2} \mathrm{SO}_{4}$ to 10,5 , and $3 \mathrm{mM}$, respectively. The five treatments were as follows: (1) the addition of BES and SM (BES+SM); (2) the addition of BES (BES); (3) the addition of SM (SM); (4) the addition of EA (EA); (5) unamended (none). The gas composition was $1-2 \%$ of $\mathrm{H}_{2}, 5 \%$ of $\mathrm{CH}_{4}$ and $93-94 \%$ of $\mathrm{N}_{2}$ in the headspace of the serum vials. The arrows indicate timepoints when ${ }^{12} \mathrm{CH}_{4} /{ }^{13} \mathrm{CH}_{4}$ was injected to reinstate the initial headspace $\mathrm{CH}_{4}$ concentration. Error bars indicate standard deviation. Error bars are not shown in $\mathbf{A}$ and $\mathbf{B}$ for visual clarity.

original sediment and the heavy DNA with a relative abundance of $0.0056 \%$ and $0.092 \%$, respectively (Fig. 7). All pmo genes were taxonomically assigned to cultured aerobic methanotrophs based on MEGAN. The gene $m m o X$, encoding soluble MMO (sMMO), was not detected in the original sediment or the heavy DNA. Methanol is subsequently oxidized by either a calcium-dependent MxaFtype or a lanthanide-dependent XoxF-type methanol dehydrogenase encoded by $m x a$ annotated as part of the mxa operon and $x O x F$, which were detected with the relative abundances of $0.135 \%$ and $0.019 \%$, respectively, in the heavy DNA. In addition to aerobic methanotrophs, some $m x a$ and $x o x F$ sequences were associated with methylotrophs. The $f d h A$ gene, encoding particulate cytochrome-linked formaldehyde dehydrogenase, was detected in the original sediment and the heavy DNA, but it was not affiliated with aerobic methanotrophs. The relative abundance of genes involved in the tetrahydromethanopterin $\left(\mathrm{H}_{4} \mathrm{MPT}\right)$-dependent oxidation of formaldehyde to formate, including fae, $m t d B$, $m c h$, and ftr [52], ranged from 0.0001 to $0.002 \%$ in the original sediment and from 0.015 to $0.044 \%$ in the heavy DNA and were all associated with aerobic methanotrophs. The relative abundance of genes potentially involved in $\mathrm{H}_{4} \mathrm{~F}$-dependent oxidation of formaldehyde to formate, including $m t d A$ and $f c h$, ranged from 0.0004 to $0.002 \%$ in the original sediment and from 0.013 to $0.015 \%$ in the heavy DNA, however, fhs, encoding formyl- $\mathrm{H}_{4} \mathrm{~F}$ synthetase, was not detected. Additionally, the genes $g f a, f r m A$, and $\operatorname{frm} B$, potentially involved in glutathione-dependent formaldehyde oxidation, were not detected in the original sediment or the heavy DNA, except for frmA, which was detected in the original sediment but was not associated with aerobic methanotrophs. These results suggest that formaldehyde was mainly oxidized by the $\mathrm{H}_{4}$ MPT-dependent pathway in the anoxic SIP incubation.

Genes potentially involved in nitrogen metabolism, including nitrogen-fixation and denitrification, were also detected in the heavy DNA. The reduction of nitrate to nitrite can be catalyzed by two different putative membrane-associated dissimilatory nitrate reductases, i.e., the cytoplasmic electrogenic enzyme complex NarGHI (narGHI) (transmembrane nitrate reductase, NAR) and the periplasmic enzyme complex NapAB (napAB) (periplasmic nitrate reductase, NAP) [26]. Of them, nap was not detected in the original sediment or the heavy DNA, but narG, narH, and narl were present and were mainly associated with aerobic methanotrophs. The genes for nas $A$, encoding assimilatory nitrate reductase was detected in the heavy DNA, but none were associated with aerobic methanotrophs. The gene annotated as encoding the copper-containing nitrite reductase, nirk, was detected in the original sediment and the heavy DNA, of which $17.9 \%$ and $54.7 \%$ were associated with aerobic methanotrophs. However, we did not detect nirS, encoding the cytochrome cd1 nitrite reductase in the original sediment or the heavy DNA. The relative abundance of nor $B C$ genes, encoding nitric oxide reductase, ranged from 0.014 to $0.017 \%$ in the heavy DNA and most were associated with aerobic methanotrophs. Additionally, the genes potentially involved in nitrogen fixation, including nifD, nifH, and nifK, and the gene hao (annotated as encoding hydroxylamine oxidoreductase), were also detected in the original sediment and the heavy DNA and were all associated with aerobic methanotrophs. 
$\mathrm{BH}$

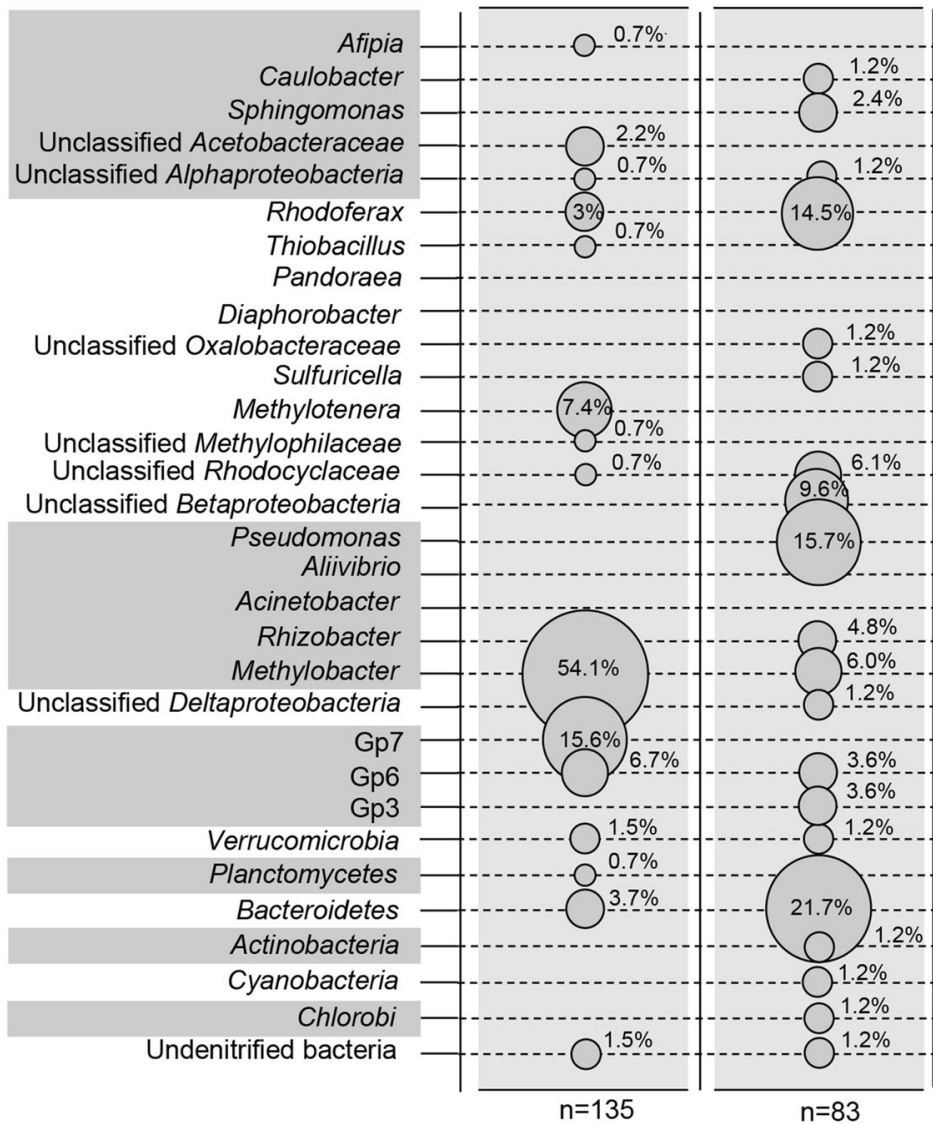

BL

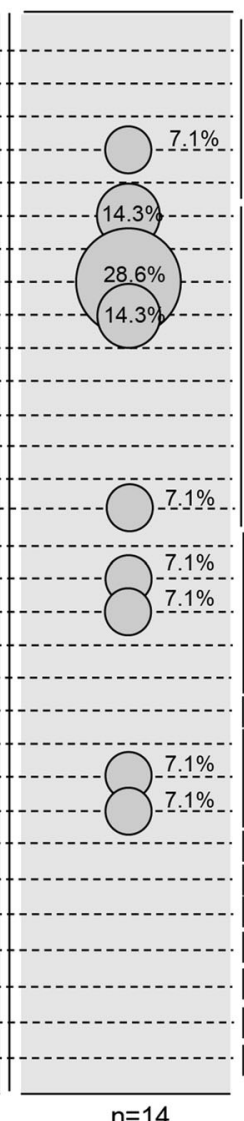

a-Proteobacteria

$\beta$-Proteobacteria

y-Proteobacteriaia

ঠ-Proteobacteria

Acidobacteria

Verrucomicrobia

Planctomycetes

Bacteroidetes

Actinobacteria

Cyanobacteria

Chlorobi

Undenitrified bacteria

Fig. 4 Phylogenetic affiliations and relative abundance of bacterial 16S rRNA gene sequences in clone libraries for the heavy (BH) and light (BL) DNA from the ${ }^{13} \mathrm{CH}_{4}$ incubation and the heavy (BC) DNA from the ${ }^{12} \mathrm{CH}_{4}$ incubation (unlabeled control). The phylogenetic affiliations of bacterial sequences were classified using the Ribosomal Database Project (RDP). The circle size in the figure corresponds to the relative abundance of the operational taxonomic units.

The genes hyaA and hyaB, encoding group $1 \mathrm{~d}[\mathrm{NiFe}]$ hydrogenase, and the genes potentially involved in bidirectional hydrogenase including hoxH, hoxY, hoxU, and hox $F$ were detected in the original sediment and were mainly associated with aerobic methanotrophs and Cyanobacteria. Of them, 5.6-72.0\% of hoxH, hyaB, and hox $Y$ were associated with aerobic methanotrophs. All hyaA, hoxU, and hoxF genes detected were affiliated with aerobic methanotrophs. The genes potentially involved in hydrogen metabolism including hydrogenase and bidirectional hydrogenase were also detected in the heavy DNA, of which over $67.1 \%$ were associated with aerobic methanotrophs. Additionally, the homologs of genes mtrA and $m t r C$, encoding $m$ trA and $m t r C$ cytochrome, which may be potentially involved in iron reduction [53], were detected in the heavy DNA. The homologs of gene cycl were also detected in the original sediment and the heavy DNA that encodes Cyc1 protein, which is a member of the cytochrome c4 family of high-redox-potential proteins and may be potentially involved in iron oxidation [54]. Over $72.2 \%$ of the detected homologs of gene cyc1 were affiliated with aerobic methanotrophs. However, we did not detect $m \operatorname{tr} B$ and $c y c 2$ genes and their homologs, which are potentially involved in iron oxidation and reduction $[52,53]$, in the original sediment or the heavy DNA.

\section{DISCUSSION}

In this study, we found that microorganisms typically classified as aerobic methanotrophs were present and active in assimilating $\mathrm{CH}_{4}$-derived carbon during anoxic incubations using sediments collected from an active $\mathrm{CH}_{4}$ seep in an Arctic lake. Aerobic methanotrophs were present in sediments down to at least $70 \mathrm{~cm}$ deep at the active $\mathrm{CH}_{4}$ seep, despite being under persistently anoxic conditions. In anoxic SIP mesocosms using lake sediments obtained from 25 to $50 \mathrm{~cm}$ deep, $\mathrm{CH}_{4}$ assimilation was dominated by Gammaproteobacterial methanotrophs, including Methylocaldum, Methylococcus, Methylomarinum, Methylomicrobium, Methylomonas, Methylosarcina, Methylovulum, and especially Methylobacter. Methylobacter has also been reported to be abundant in the Beggiatoa mats and the anoxic center of the Haakon Mosby Mud Volcano in $\mathrm{CH}_{4}$-rich sediments with an $\mathrm{O}_{2}$ penetration depth of only a few millimeters or less $[19,55,56]$. Although counterintuitive, similar findings of aerobic methanotrophs thriving under anoxic conditions and actively oxidizing $\mathrm{CH}_{4}$ despite their obligate aerobe designation have been reported from other environments as well [19, 22-24, 57, 58].

Metagenomic analyses of heavy DNA revealed that the Gammaproteobacterial methanotrophs active in our anoxic SIP sediment experiment have substantial metabolic flexibility. In addition to having genes associated with the production of the $\mathrm{CH}_{4}$-oxidation intermediates such as methanol, formaldehyde, and formate and the $\mathrm{H}_{4}$ MPT-dependent oxidation of formaldehyde, methanotrophs that assimilated $\mathrm{CH}_{4}$-derived carbon had genes for nitrogen cycling and hydrogen processing. Despite the presence of genes associated with nitrate reduction in methanotrophs, $\mathrm{CH}_{4}$ oxidation was unlikely to be coupled to denitrification in the SIP mesocosms or in situ, owing to the extremely low levels of dissolved inorganic nitrogen (0.6-1.3 $\mu \mathrm{M}$, including $\mathrm{NH}_{4}{ }^{+}-\mathrm{N}$ concentration of $0-0.7 \mu \mathrm{M}$ and the 


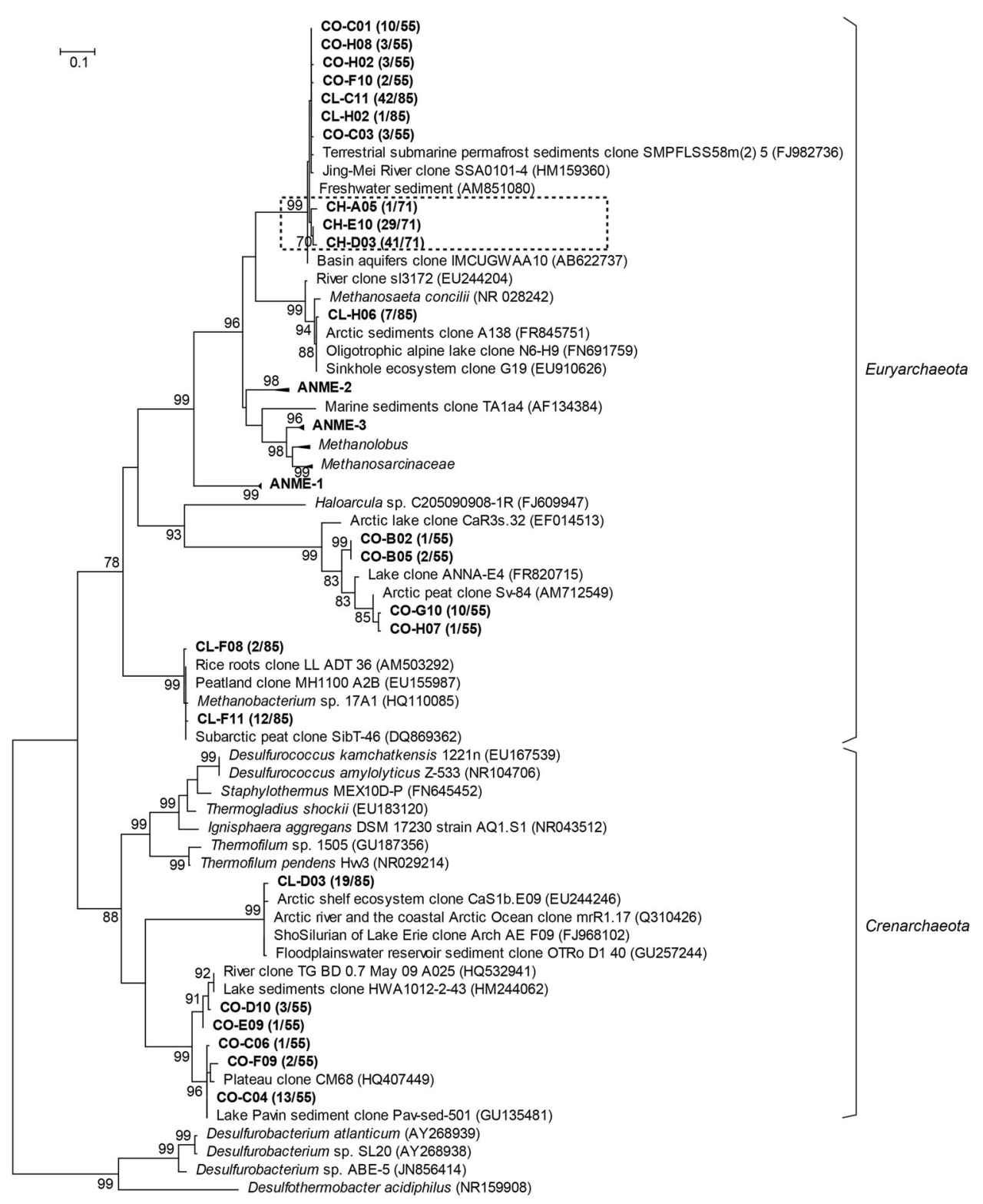

Fig. 5 Maximum-likelihood tree of representative archaeal 16S rRNA gene sequences directly amplified from the heavy (CH) and light (CL) fractions from ${ }^{13} \mathrm{CH}_{4}$ incubations and original sediment DNA (CO). The scale bar represents 0.1 substitutions per nucleotide position. Bootstrap values $>70$ are shown. The first number (before the "/") in parentheses is the number of clones in the same operational taxonomic unit (OTU) assigned by CAP3 sequence assembly program with $97 \%$ similarity; the number after the "/" in parentheses is the total clones in $\mathrm{CH}, \mathrm{CL}$, and $\mathrm{CO}$ libraries, respectively.

$\mathrm{NO}_{3}{ }^{-}-\mathrm{N}$ concentration of $0.6 \mu \mathrm{M}$ in July water samples). $\mathrm{CH}_{4}$ oxidation also was apparently not linked to sulfate reduction, since amendment of mesocosms with sulfate or an inhibitor of sulfate reduction had no effect on $\mathrm{CH}_{4}$ oxidation. However, iron was notably abundant in sediments in levels stoichiometrically sufficient to serve as an electron acceptor for oxidation of the high quantity of $\mathrm{CH}_{4}$ in the SIP mesocosms, where $\mathrm{Fe}^{3+}$ molar mass in sediments was 4.46 times of that of $\mathrm{CH}_{4}$ consumption in the mesocosms (calculated by $\mathrm{Fe}_{3} \mathrm{O}_{4}$ based on the $\mathrm{X}$-ray diffraction analysis, Supplementary Table S1; As noted previously, there is some possibility of iron oxidation during sample storage that may have contributed to $\mathrm{Fe}^{3+}$ levels some degree) (Supplementary information). Organisms that derived carbon from $\mathrm{CH}_{4}$ included known iron reducers such as Desulfovibrio and Shewanella [59]. Additionally, the genes possibly involved in iron oxidation and reduction such as mtrAC and cyc1 were also present in the heavy ${ }^{13} \mathrm{C}$-DNA. Based on the evidence, we propose that aerobic methanotrophs were active in assimilating $\mathrm{CH}_{4}$ or $\mathrm{CH}_{4}$-derived intermediates under anoxic conditions in these sediments, and that this might be coupled to iron reduction, although further study is required to definitively determine which electron acceptor(s) are utilized in these sediments. Furthermore, these aerobic methanotrophs were metabolically flexible, with the genetic potential to perform some nitrogen cycling and hydrogen metabolism processes that might aid in sustaining their anoxic methanotrophy under certain conditions (Fig. 8).

Aerobic methanotrophs are known to possess genes associated with nitrogen metabolism and can contribute to nitrogen cycling in the environment $[26,60,61]$. Although denitrification was unlikely to be coupled to $\mathrm{CH}_{4}$ oxidation in our incubations or in situ due to low inorganic nitrogen levels, the active aerobic methanotrophs possessed the genetic potential to do so, which might have relevance in more $\mathrm{N}$-rich environments. Genes for denitrification, including narGHI, nirk, and norBC (Fig. 8), have been proposed as a means of energy conservation for aerobic 
A

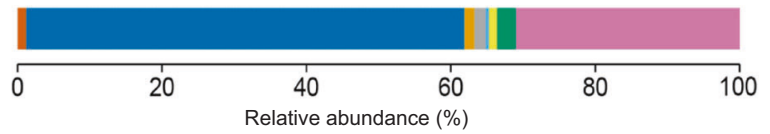

B

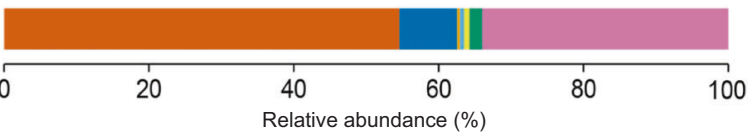

Actinobacteria
C

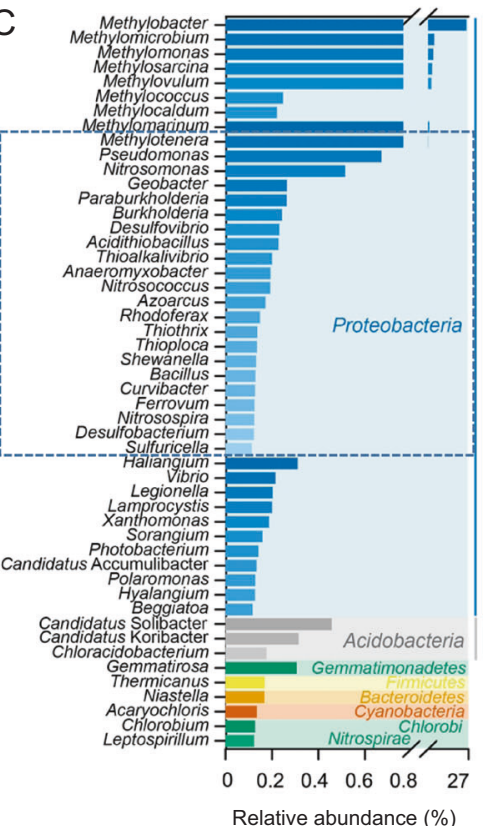

$\mathrm{D}$

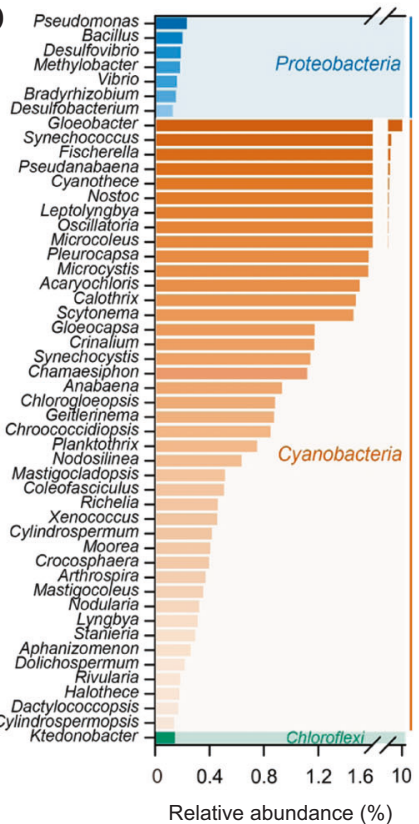

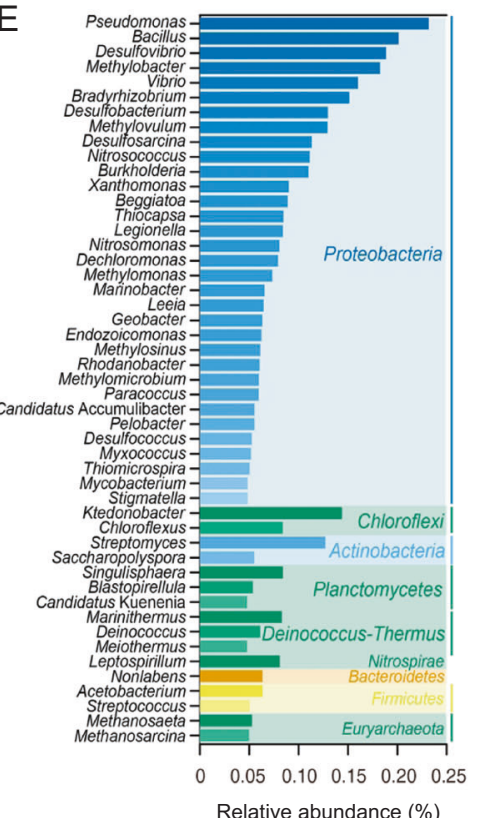

Fig. 6 Shotgun metagenomic sequencing data for total DNA from the sediment cores (the original sediment of 25-50 cm depth) and the heavy DNA from its ${ }^{13} \mathrm{CH}_{4}$-incubated samples. The phylum-level microbial community composition in the heavy DNA (A) and the original sediment (B), relative abundance of the top 50 genera in the heavy DNA (C), relative abundance of the top 50 genera in the original sediment (D), and the top 100 genera belonging to non-Cyanobacteria phyla in the original sediment (E). The genera affiliated with Proteobacteria in C identified with dotted rectangles may be associated with the metabolism of nitrogen, sulfide, metal (mainly iron) and electron transport based on reports in the literature (Supplementary Table S2). Taxonomic assignment of predicted genes was carried out using MEGAN (version 5.3) and subjected to BLASTX analysis using the NCBI-nr database (2016-09). The relative abundance of members of each taxonomic level was approximated by calculating the number of the gene reads affiliated with that taxonomic level to the total number of assembled reads per metagenome.

methanotrophs under $\mathrm{O}_{2}$-limitated conditions [26]. In our study, nap was not detected but narG, narH, and narl were present in the original sediment and the heavy DNA, and were mainly associated with aerobic methanotrophs, based on taxonomic classification by MEGAN. This indicated that aerobic methanotrophs could potentially utilize NAR during denitrification rather than NAP, which provides theoretically greater energy conservation through pmf-driven ATP synthesis under anoxic conditions [26, 62]. More relevant to our $\mathrm{N}$-limited system, genes potentially involved in nitrogen fixation including nifD, nifH, and nifK, and the gene hao annotated as encoding hydroxylamine oxidoreductase were also detected in heavy DNA and were annotated as associated with aerobic methanotrophs. This indicated that some aerobic methanotrophs might potentially fix nitrogen and use hydroxylamine oxidoreductase to oxidize and detoxify hydroxylamine [61], which might supply nitrogen for microbial metabolism.

The aerobic methanotrophs active in our SIP mesocosms also possessed the genetic potential for hydrogen metabolism. Molecular hydrogen is thought to be an alternative means for energy conservation in aerobic methanotrophs, providing an energetic advantage over methanotrophy under $\mathrm{O}_{2}$-limited conditions [63]. Molecular hydrogen also can be used by aerobic methanotrophs such as Methylococcus capsulatus (Bath) as a source of reducing power for $\mathrm{CH}_{4}$ oxidation, driving $\mathrm{MMO}$ activities in the presence or absence of $\mathrm{O}_{2}[64,65]$. However, the mechanism for hydrogen-driven MMO activity has not been investigated in detail. Respiratory-linked hyaAB hydrogenases affiliated with aerobic methanotrophs were present in our heavy DNA, and might potentially provide energy to sustain chemolithoautotrophic growth of aerobic methanotrophs on hydrogen $[66,67]$. Mixotrophic growth (oxidation of both hydrogen and $\mathrm{CH}_{4}$ ) in the thermoacidophile Methylacidiphilum sp. RTK17.1 has been observed under $\mathrm{O}_{2}$-limited conditions and was proposed to provide a competitive advantage over obligate methanotrophy at oxic/anoxic soil boundaries within geothermal environments [68]. Hydrogen metabolism in aerobic methanotrophs has also been reported to increase the production of intracellular glycogen reservoirs under $\mathrm{O}_{2}$-limited conditions $[63,68]$, which can serve to store carbon and energy and to maintain intracellular redox states. And, these hydrogen-driven MMO activities of aerobic methanotrophs have been observed under both $\mathrm{O}_{2}$-limited and anoxic conditions [64], making their role in sediment systems worthy of future investigation.

The diverse metabolic capabilities of the organisms assimilating $\mathrm{CH}_{4}$ in our mesocosms raised the question of which electron acceptor(s) might be actively utilized by the consortium as it oxidized $\mathrm{CH}_{4}$ or its intermediates, such as methanol and formaldehyde (given the detection of $\mathrm{H}_{4}$ MPT-dependent oxidation pathway, which is common in AOM [9]). In addition to aerobic methanotrophs, microorganisms associated with the metabolism of nitrogen, sulfide, metal (mainly iron), and electron transport such as Desulfovibrio, Pseudomonas, Geobacter, Rhodoferax Shewanella, Acidithiobacillus, and Chlorobium were also active in assimilating $\mathrm{CH}_{4}$-derived carbon. As noted previously, conditions 
A

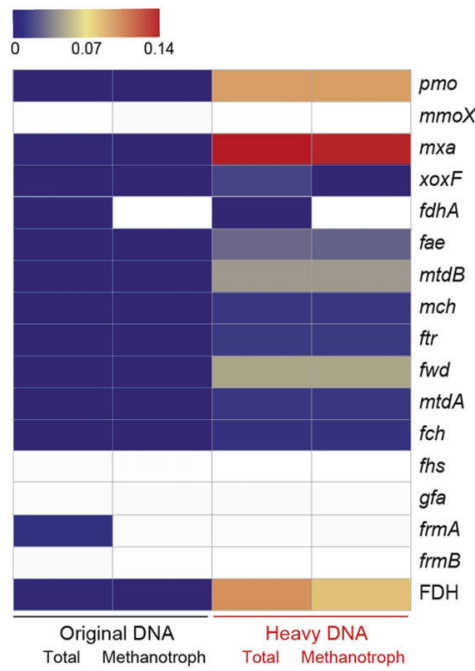

B

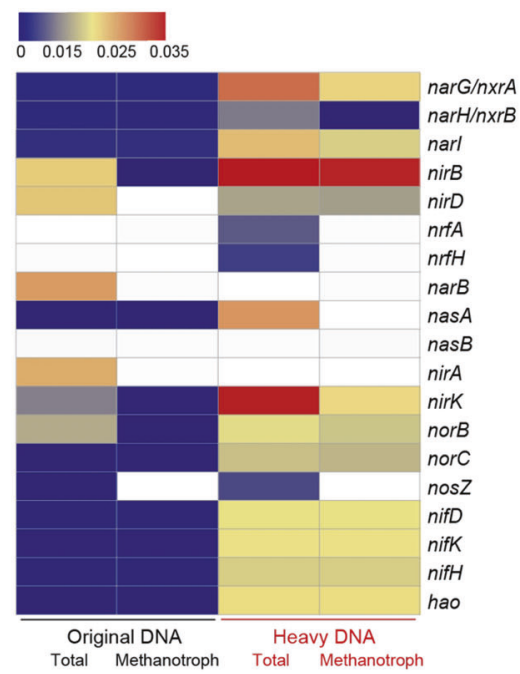

c

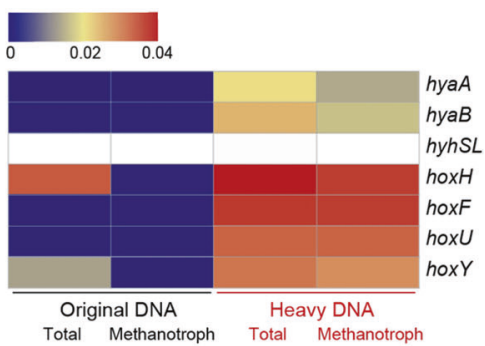

D

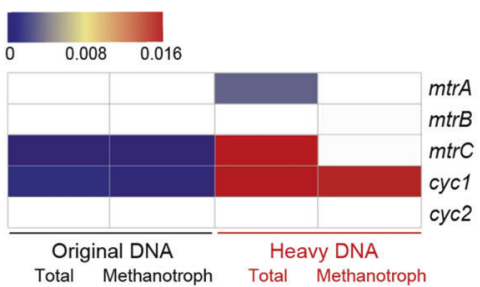

Fig. 7 A heatmap of the relative abundance of the main genes involved in $\mathrm{CH}_{4}$ oxidation, nitrogen, hydrogen and iron metabolism in the heavy DNA and the original sediment. $\mathrm{CH}_{4}$ oxidation $(\mathbf{A})$, nitrogen metabolism (B), hydrogenase (including uptake hydrogenase and bidirectional hydrogenase) (C), and genes possibly involved in iron oxidation and reduction (D). The numbers in the scales show the relative abundance of assembled genes based on read mapping. White denotes that the gene was not detected. "Total" refers to the total relative abundance of the genes; "methanotroph" refers to the genes assigned as the known aerobic methanotrophs using MEGAN (version 5.3) and BLASTX analysis using the NCBI-nr database (2016-09).

in situ and in our incubations made denitrification and sulfate reduction highly unlikely, we suspected that the $\mathrm{H}_{4}$ MPTdependent oxidation of formaldehyde might be achieved mainly with metal reduction, specifically iron, due to the sediments being very iron rich. ANME were also detected in the heavy DNA that had a $99 \%$ similarity to anaerobic freshwater sediment clone Cad24-73 (AM851080) [50], an organism taxonomically related to the Methanoperedenaceae family, which has the ability to oxidize $\mathrm{CH}_{4}$ coupled to iron reduction $[16,17]$. Moreover, two predicted genes were taxonomically assigned to microbes that were abundant in the heavy DNA: Acidithiobacillus, the only autotrophic bacterial genus that includes species capable of anaerobic sulfur oxidation with ferric iron as an electron acceptor $[69,70]$, and the iron-oxidizing sulfur bacterium Chlorobium ferrooxidans. The active cycling of iron might aid in providing electron acceptors for the oxidation of $\mathrm{CH}_{4}$ and its metabolites.

The potential free energy for $\mathrm{CH}_{4}$ oxidation coupled to iron reduction was energetically favorable in our SIP microcosms, based on simplified free energy yield estimates: $\mathrm{Fe}(\mathrm{OH})_{3}, \mathrm{CH}_{4}+8 \mathrm{Fe}(\mathrm{OH})_{3}$ $+15 \mathrm{H}^{+} \rightarrow \mathrm{HCO}_{3}^{-}+8 \mathrm{Fe}^{2+}+21 \mathrm{H}_{2} \mathrm{O} \quad \Delta \mathrm{G}=-341.2 \mathrm{~kJ} \mathrm{~mol}^{-1}$ (Supplementary information). In other lake systems, the growth of Gammaproteobacterial methanotrophs have been stimulated by the addition of $\mathrm{Fe}^{3+}$ under anoxic conditions with a $\mathrm{CH}_{4}$ assimilation of $7.5 \pm 2.1 \mathrm{fmol} \mathrm{C}$ cell $^{-1} \mathrm{~d}^{-1}$ [22]. And, in a sub-Arctic lake sediment in Alaska, iron was also identified as a potential electron acceptor supporting $\mathrm{CH}_{4}$ oxidation [19]. The mechanism linking methanotrophs designated as aerobes with concurrent metal reduction under anoxic conditions is still not clear.

A co-culture-based SIP study of syntrophic AOM coupled to iron reduction revealed that methanotrophic bacterium Methylomonas had $m t d$, encoding methylene- $\mathrm{H}_{4}$ MPT dehydrogenase, which was absent in the heavy DNA of syntrophic partner Methanobacterium. This was likely due to AOM intermediates being used as an electron source for ferrihydrite reduction by the partner bacterium [71]. Additionally, potential homologs of the gene $m t r C$ (encoding mtrC cytochrome, which may be potentially involved in iron reduction [53]) detected in the original sediment and the heavy DNA were affiliated with aerobic methanotrophs, although an more detailed analysis revealed them to be hypothetical membrane fusion proteins and their function was not clear. This suggested that aerobic methanotrophs might potentially transfer electrons to solid minerals [72], although further verification is needed. The use of solid external electron acceptors such as iron oxides and electrodes may be a survival strategy of methanotrophs to maintain their intracellular redox state in the presence of electron donors such as formate and methanol [73]. Future experiments investigating the role and mechanisms of iron reduction by microbial consortia are warranted for iron-rich, $\mathrm{O}_{2}-$ limited systems such as our Arctic lake sediments.

A lower ratio of $\mathrm{HCl}$-extractable $\mathrm{Fe}^{2+}$ to total $\mathrm{Fe}$ in the deeper sediments in situ pointed to a high redox potential in the deeper seep sediment under ice-free conditions compared to the ice-covered season, although we cannot entirely rule out that sample storage may have enabled iron oxidation leading to some measurement error of $\mathrm{Fe}^{2+}$ (Fig. 1). The apparent iron redox gradient along the sediment depth profile might be attributed to extensive aeration of lake water and sediments during the open water season due to wave action. The active turbation and settling of sediments at this seep might enable aerated water to penetrate deeper into sediments and oxidize iron. Additionally, the Fe and $\mathrm{CH}_{4}$ profiles in the $\mathrm{CH}_{4}$ seep site suggest that reduction of this oxidized iron $\left(\mathrm{Fe}^{3+}\right)$ may be spatially correlated with the oxidation of $\mathrm{CH}_{4}$ or its intermediates like formaldehyde. Alternatively, iron reduction may be linked with the decay of organic matter originating from microbial biomass, including the primary producers Cyanobacteria, which were abundant in sediment communities. A high Fe content was detected in the sediment 10-15-cm deep under ice cover in May. This might be attributed to reduced $\mathrm{Fe}^{2+}$ being soluble and subject to upward flux to $10-15 \mathrm{~cm}$, where it could be oxidized in the later summer/fall. Then, the $\mathrm{Fe}^{3+}$ might potentially serve as an electron acceptor reservoir supporting $\mathrm{CH}_{4}$ oxidation as ice cover occurred and $\mathrm{O}_{2}$ levels declined.

Cyanobacteria were dominant members of our $25-50-\mathrm{cm}$ deep original sediment community, likely due to turbation and settling of sediments at this highly active seep (Fig. 6D). Also, Cyanobacteria assimilated $\mathrm{CH}_{4}$-derived carbon in anoxic SIP mesocosms, including members of the genera Acaryochloris, Pseudanabaena, Scytonema, Nostoc, Leptolyngbya, Oscillatoria, and Gloeocapsa (Fig. 6C). The presence of metabolically active Cyanobacteria in anoxic mesocosms might be attributed to the cross-feeding of $\mathrm{CH}_{4}$-derived carbon, owing to their ability to 


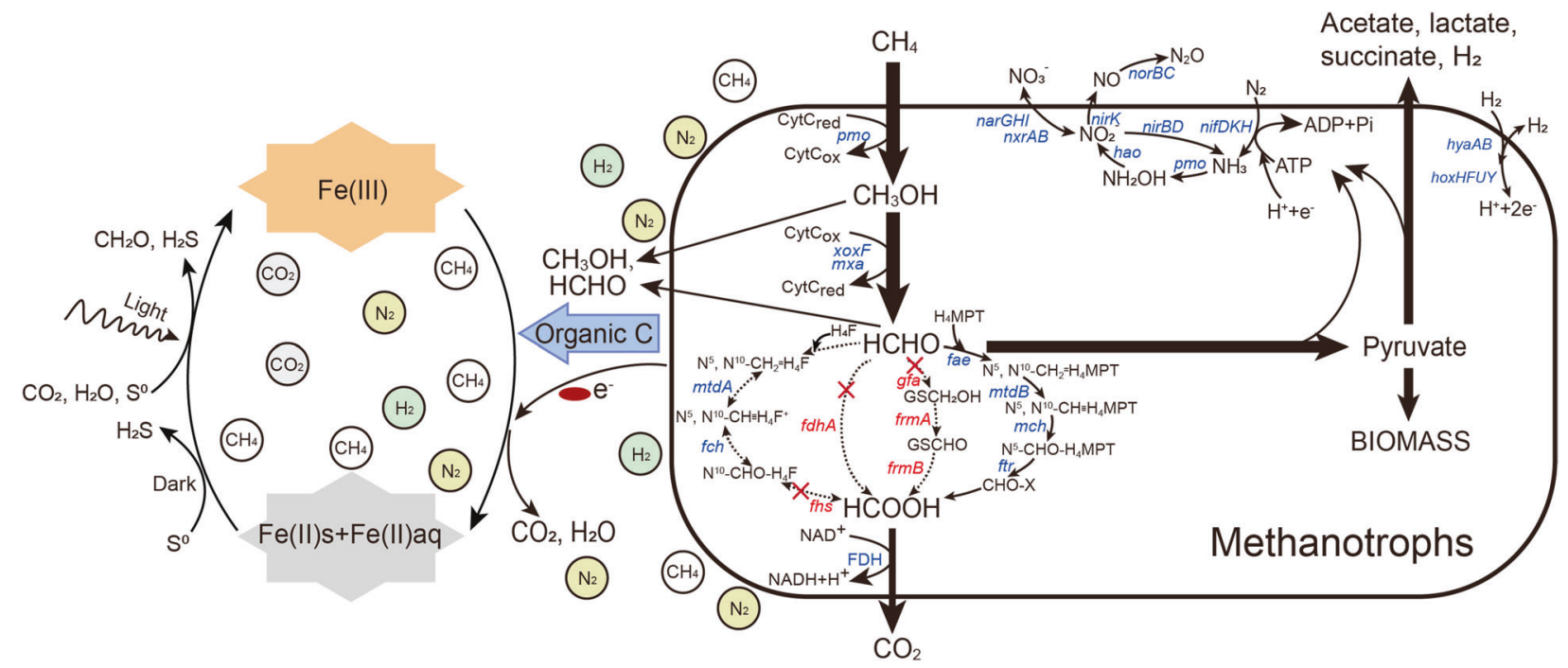

Fig. 8 The proposed mechanisms of aerobic methanotrophic metabolism in the anoxic SIP microcosms, including CH4-derived carbon secretion and oxidation, as well as nitrogen and hydrogen metabolism for sustaining methanotrophy coupled to iron reduction. The genes in red were not detected using metagenomic analysis in the heavy DNA from the ${ }^{13} \mathrm{CH}_{4}$ incubation and red $\mathrm{x}$-symbols $(\mathrm{x})$ denote pathways was unlikely involved in anaerobic $\mathrm{CH}_{4}$ oxidation due to lack of detection in the SIP-metagenomics data. The red oval labeled $\mathrm{e}^{-}$ shows extracellular electron transfer from the cell to Fe (III). The organic C released by methanotrophs may stimulate Fe (III) reduction via dissimilatory iron-reducing bacteria. Based on the metabolic characteristics of potential iron-cycling microbes in the heavy DNA, e.g., Chlorobium ferrooxidans, and the minimal light exposure during the SIP experiment, Fe (II) oxidation might be coupled to sulfur metabolism under the light or dark conditions, as shown on the left side of the figure. The SIP microcosm headspace consisted of 1-2\% $\mathrm{H}_{2}, 5 \% \mathrm{CH}_{4}$, and 93-94\% $\mathrm{N}_{2}$.

grow mixotrophically or heterotrophically on organic matter, which also might enable Cyanobacteria to survive through nonphotosynthetic mechanisms after burial deeper into the sediment [74].

The analysis of $\delta^{18} \mathrm{O}$ enrichment of $\mathrm{CO}_{2}$ derived from ${ }^{18} \mathrm{O}-\mathrm{H}_{2} \mathrm{O}$ in the headspace of serum vials showed that it increased over time within the 20-day incubation (Fig. 3D). There are several possible pathways for the conversion of ${ }^{18} \mathrm{O}-\mathrm{H}_{2} \mathrm{O}$ into ${ }^{18} \mathrm{O}-\mathrm{CO}_{2}$ such as (1) the degradation of organic matter, (2) hydrolysis of $\mathrm{H}_{2} \mathrm{O}$ into $\mathrm{OH}^{-}$ and then conversion into $\mathrm{CO}_{2}$, and (3) ${ }^{18} \mathrm{O}$ exchange between $\mathrm{CO}_{2}$ and $\mathrm{H}_{2} \mathrm{O}[15,75-77]$. Further studies need to be conducted to determine which process(es) were involved in the conversion of ${ }^{18} \mathrm{O}-\mathrm{H}_{2} \mathrm{O}$ into ${ }^{18} \mathrm{O}-\mathrm{CO}_{2}$ in the SIP mesocosms. Additionally, we also cannot rule out the possibility of some low-level ${ }^{18} \mathrm{O}_{2}$ production from ${ }^{18} \mathrm{O}-\mathrm{H}_{2} \mathrm{O}$ via photosynthesis by Cyanobacteria during the SIP incubation, followed by the use of this labeled $\mathrm{O}_{2}$ in $\mathrm{CH}_{4}$ oxidation, since the serum vials were exposed to ambient laboratory lighting for 4-6 h every 20 days when determining gas concentrations and exchanging headspace gas. Considering the minimal light exposure during the SIP experiment, we estimated that any possible $\mathrm{O}_{2}$ production from photosynthesis was very low (Supplementary information). Although we also could not exclude rare $\mathrm{O}_{2}$ leakage during sampling or flushing of bottles, $\mathrm{O}_{2}$ produced in mesocosms on these rare occasions would be insufficient to explain the large quantity of $\mathrm{CH}_{4}$ oxidized in the otherwise anoxic mesocosms.

Taken together, our study indicated that aerobic methanotrophs were abundant and active in the deeper seep-associated sediments and in the anoxic SIP mesocosms. Aerobic methanotrophs possessed metabolic flexibility to produce $\mathrm{CH}_{4}$ oxidation intermediates and to utilize them (i.e. via the $\mathrm{H}_{4}$ MPT-dependent oxidation of formaldehyde), as well as the potential capacity for hydrogen oxidation and denitrification using narGHI, nirK, and norBC. These capabilities might provide these organisms additional means for survival through conserving energy and maintaining a favorable intracellular redox state under anoxic conditions. Based on the geochemistry of the lake and sediments, including low inorganic nitrogen and sulfate levels, iron, which is highly abundant, was identified as the most likely potential electron acceptor. These findings contribute to the effort to understand $\mathrm{CH}_{4}$ oxidation under anoxic conditions and to reconsider the role that methanotrophs designated as obligately aerobic may play in the $\mathrm{CH}_{4}$ cycle in the Arctic, especially lakes that experience extended $\mathrm{O}_{2}$ limitations annually while ice covered.

\section{REFERENCES}

1. Saunois $M$, Stavert AR, Poulter $B$, Bousquet $P$, Canadell JG, Jackson RB, et al. The global methane budget 2000-2017. Earth Syst Sci Data. 2020;12:1561-623.

2. Reeburgh WS. Oceanic methane biogeochemistry. Chem Rev. 2007;107:486-513.

3. Weber T, Wiseman NA, Kock A. Global ocean methane emissions dominated by shallow coastal waters. Nat Commun. 2019;10:4584.

4. He R, Wooller MJ, Pohlman JW, Quensen J, Tiedje JM, Leigh MB. Shifts in identity and activity of methanotrophs in arctic lake sediments in response to temperature changes. Appl Environ Microb. 2012;78:4715-23.

5. Phelps AR, Peterson KM, Jeffries MO. Methane efflux from high-latitude lakes during spring ice melt. J Geophys Res Atmos. 1998;103:29029-36.

6. Walter KM, Smith LC, Chapin FS. Methane bubbling from northern lakes: present and future contributions to the global methane budget. Philos Trans A Math Phys Eng Sci. 2007;365:1657-76.

7. Wik M, Varner RK, Anthony KW, Maclntyre S, Bastviken D. Climate-sensitive northern lakes and ponds are critical components of methane release. Nat Geosci. 2016;9:99-105.

8. Knittel K, Boetius A. Anaerobic oxidation of methane: progress with an unknown process. Annu Rev Microbiol. 2009;63:311-34.

9. Timmers PHA, Welte CU, Koehorst JJ, Plugge CM, Jetten MSM, Stams AJM. Reverse methanogenesis and respiration in methanotrophic archaea. Archaea. 2017;2017:1654237.

10. Shen LD, Ouyang L, Zhu Y, Trimmer M. Active pathways of anaerobic methane oxidation across contrasting riverbeds. ISME J. 2019;13:752-66.

11. Valenzuela El, Cervantes FJ. The role of humic substances in mitigating greenhouse gases emissions: Current knowledge and research gaps. Sci Total Environ. 2021;750:141677.

12. Orphan VJ, House $\mathrm{CH}$, Hinrichs KU, McKeegan KD, DeLong EF. Multiple archaeal groups mediate methane oxidation in anoxic cold seep sediments. Proc Natl Acad Sci USA. 2002;99:7663-8.

13. Orphan VJ, House $\mathrm{CH}$, Hinrichs KU, McKeegan KD, DeLong EF. Methaneconsuming archaea revealed by directly coupled isotopic and phylogenetic analysis. Science. 2001;293:484-7. 
14. Haroon MF, Hu S, Shi $Y$, Imelfort M, Keller J, Hugenholtz $P$, et al. Anaerobic oxidation of methane coupled to nitrate reduction in a novel archaeal lineage. Nature. 2013;500:567-70.

15. Cai C, Leu AO, Xie GJ, Guo JH, Feng YX, Zhao JX, et al. A methanotrophic archaeon couples anaerobic oxidation of methane to $\mathrm{Fe}(\mathrm{III})$ reduction. ISME J. 2018;12:1929-39.

16. Ettwig KF, Zhu B, Speth D, Keltjens JT, Jetten MSM, Kartal B. Archaea catalyze irondependent anaerobic oxidation of methane. Proc Natl Acad Sci USA. 2016;113:12792-6.

17. Leu AO, Cai C, Mcllroy SJ, Southam G, Orphan VJ, Yuan ZG, et al. Anaerobic methane oxidation coupled to manganese reduction by members of the Methanoperedenaceae. ISME J. 2020;14:1030-41.

18. Ettwig KF, Butler MK, Le Paslier D, Pelletier E, Mangenot S, Kuypers MMM, et al. Nitrite-driven anaerobic methane oxidation by oxygenic bacteria. Nature. 2010;464:543-8

19. Martinez-Cruz K, Leewis MC, Herriott IC, Sepulveda-Jauregui A, Anthony KW, Thalasso $F$, et al. Anaerobic oxidation of methane by aerobic methanotrophs in sub-Arctic lake sediments. Sci Total Environ. 2017;607:23-31.

20. He R, Wooller MJ, Pohlman JW, Quensen J, Tiedje JM, Leigh MB. Diversity of active aerobic methanotrophs along depth profiles of arctic and subarctic lake water column and sediments. ISME J. 2012;6:1937-48.

21. Bowman JP, Sly LI, Nichols PD, Hayward AC. Revised taxonomy of the methanotrophs: description of Methylobacter gen. nov., validation of Methylosinus and Methylocystis species, and a proposal that the family Methylococcaceae includes only the group I methanotrophs. Int J Syst Bacteriol. 1993;43:735-53.

22. Oswald K, Milucka J, Brand A, Hach P, Littmann S, Wehrli B, et al. Aerobic gammaproteobacterial methanotrophs mitigate methane emissions from oxic and anoxic lake waters. Limnol Oceanogr. 2016;61:S101-18.

23. Cabrol L, Thalasso F, Gandois L, Sepulveda-Jauregui A, Martinez-Cruz K, Teisserenc $\mathrm{R}$, et al. Anaerobic oxidation of methane and associated microbiome in anoxic water of Northwestern Siberian lakes. Sci Total Environ. 2020;736:139588.

24. Milucka J, Kirf M, Lu L, Krupke A, Lam P, Littmann S, et al. Methane oxidation coupled to oxygenic photosynthesis in anoxic waters. ISME J. 2015;9:1991-2002.

25. Kalyuzhnaya MG, Yang S, Rozova ON, Smalley NE, Clubb J, Lamb A, et al. Highly efficient methane biocatalysis revealed in a methanotrophic bacterium. Nat Commun. 2013;4:2785.

26. Kits KD, Klotz MG, Stein LY. Methane oxidation coupled to nitrate reduction under hypoxia by the Gammaproteobacterium Methylomonas denitrificans, sp. nov. type strain FJG1. Environ Microbiol. 2015;17:3219-32.

27. Eberl DD. Quantitative mineralogy of the Yukon River system: variations with reach and season, and determining sediment provenance. Am Mineral. 2004;89:1784-94.

28. Lipson DA, Raab TK, Goria D, Zlamal J. The contribution of Fe(III) and humic acid reduction to ecosystem respiration in drained thaw lake basins of the Arctic Coastal Plain. Glob Biogeochem Cycles 2013;27:399-409.

29. Li WB, Yao J, Tao PP, Guo MT, Feng XY, He YN, et al. A comparative study on two extraction procedures in speciation of iron in municipal solid waste. $J$ Hazard Mater. 2010;182:640-8.

30. Oremland RS, Taylor BF. Sulfate reduction and methanogenesis in marine sediments. Geochim Cosmochim Acta. 1978;42:209-14.

31. Glassburn CL, Potter BA, Clark JL, Reuther JD, Bruning DL, Wooller MJ. Strontium and oxygen isotope profiles of sequentially sampled modern bison (bison bison bison) teeth from interior Alaska as proxies of seasonal mobility. Arctic. 2018;71:183-200.

32. He R, Wooller MJ, Pohlman JW, Catranis C, Quensen J, Tiedje JM, et al. Identification of functionally active aerobic methanotrophs in sediments from an arctic lake using stable isotope probing. Environ Microbiol. 2012;14:1403-19.

33. Leigh MB, Pellizari VH, Uhlik O, Sutka R, Rodrigues J, Ostrom NE, et al. Biphenylutilizing bacteria and their functional genes in a pine root zone contaminated with polychlorinated biphenyls (PCBs). ISME J. 2007;1:134-48.

34. Swan BK, Ehrhardt CJ, Reifel KM, Moreno LI, Valentine DL. Archaeal and bacterial communities respond differently to environmental gradients in anoxic sediments of a California hypersaline lake, the salton sea. Appl Environ Microb. 2010;76:757-68.

35. Dedysh SN, Liesack W, Khmelenina VN, Suzina NE, Trotsenko YA, Semrau JD, et al. Methylocella palustris gen. nov., sp. nov., a new methane-oxidizing acidophilic bacterium from peat bogs, representing a novel subtype of serine-pathway methanotrophs. Int J Syst Evol Microbiol. 2000;50:955-69.

36. Vorobev AV, Baani M, Doronina NV, Brady AL, Liesack W, Dunfield PF, et al. Methyloferula stellata gen. nov. sp. nov. an acidophilic, obligately methanotrophic bacterium that possesses only a soluble methane monooxygenase. Int J Syst Evol Microbiol. 2011;61:2456-63.

37. Kolb S, Knief C, Stubner S, Conrad R. Quantitative detection of methanotrophs in soil by novel pmoA-targeted real-time PCR assays. Appl Environ Microbiol. 2003;69:2423-9.
38. Fierer N, Schimel JP, Holden PA. Influence of drying-rewetting frequency on soil bacterial community structure. Micro Ecol. 2003;45:63-71.

39. Fierer N, Jackson RB. The diversity and biogeography of soil bacterial communities. Proc Natl Acad Sci USA. 2006;103:626-31.

40. Huang $X Q$, Madan A. CAP3: a DNA sequence assembly program. Genome Res. 1999;9:868-77.

41. Ma RC, Chu YX, Wang J, Wang C, Leigh MB, Chen Y, et al. Stable-isotopic and metagenomic analyses reveal metabolic and microbial link of aerobic methane oxidation coupled to denitrification at different O2 levels. Sci Total Environ. 2020;764:142901.

42. Luo RB, Liu BH, Xie YL, Li ZY, Huang WH, Yuan JY, et al. SOAPdenovo2: an empirically improved memory-efficient short-read de novo assembler. GigaScience. 2012;1:18.

43. You MS, Yue Z, He WY, Yang XH, Yang G, Xie M, et al. A heterozygous moth genome provides insights into herbivory and detoxification. Nat Genet. 2013;45:220-5.

44. Zhu WH, Lomsadze $A$, Borodovsky $M$. Ab initio gene identification in metagenomic sequences. Nucleic Acids Res. 2010;38:e132.

45. Guo JH, Peng YZ, Fan L, Zhang L, Ni BJ, Kartal B, et al. Metagenomic analysis of anammox communities in three different microbial aggregates. Environ Microbiol. 2016;18:2979-93.

46. Li WZ, Godzik A. Cd-hit: a fast program for clustering and comparing large sets of protein or nucleotide sequences. Bioinformatics. 2006;22:1658-9.

47. Liu SP, Chen QL, Zou HJ, Yu YJ, Zhou ZL, Mao J, et al. A metagenomic analysis of the relationship between microorganisms and flavor development in Shaoxing mechanized huangjiu fermentation mashes. Int J Food Microbiol. 2019;303:9-18.

48. Francis OE, Bendall M, Manimaran S, Hong CJ, Clement NL, Castro-Nallar E, et al. Pathoscope: Species identification and strain attribution with unassembled sequencing data. Genome Res. 2013;23:1721-9.

49. He Y, Feng XY, Fang J, Zhang Y, Xiao X. Metagenome and metatranscriptome revealed a highly active and intensive sulfur cycle in an oil-immersed hydrothermal chimney in Guaymas basin. Front Microbiol. 2015;6:1236.

50. Schubert CJ, Vazquez F, Losekann-Behrens T, Knittel K, Tonolla M, Boetius A. Evidence for anaerobic oxidation of methane in sediments of a freshwater system (Lago di Cadagno). FEMS Microbiol Ecol. 2011;76:26-38.

51. He R, Wooller MJ, Pohlman JW, Tiedje JM, Leigh MB. Methane-derived carbon flow through microbial communities in arctic lake sediments. Environ Microbiol. 2015;17:3233-50.

52. Vorholt JA. Cofactor-dependent formaldehyde oxidation in methylotrophic bacteria. Arch Microbiol. 2002;178:239-49.

53. Garber Al, Nealson $\mathrm{KH}$, Okamoto A, McAllister SM, Chan CS, Barco RA, et al FeGenie: a comprehensive tool for the identification of iron genes and iron gene neighborhoods in genome and metagenome assemblies. Front Microbiol. 2020;11:37.

54. Barco A, Emerson D, Sylvan JB, Orcutt BN, Meyers MEJ, Ramírez GA, et al. New insight into microbial iron oxidation as revealed by the proteomic profile of an obligate iron-oxidizing chemolithoautotroph roman. Appl Environ Microbiol. 2015;81:5927-37.

55. De Beer D, Sauter E, Niemann H, Kaul N, Foucher JP, Witte U, et al. In situ fluxes and zonation of microbial activity in surface sediments of the Hakon Mosby Mud Volcano. Limnol Oceanogr. 2006;51:1315-31.

56. Lösekann T, Knittel K, Nadalig T, Fuchs B, Niemann H, Boetius A, et al. Diversity and abundance of aerobic and anaerobic methane oxidizers at the Haakon Mosby mud volcano, Barents Sea. Appl Environ Microb. 2007:73:3348-62.

57. Blees J, Niemann H, Wenk CB, Zopfi J, Schubert CJ, Kirf MK, et al. Micro-aerobic bacterial methane oxidation in the chemocline and anoxic water column of deep south-Alpine Lake Lugano (Switzerland). Limnol Oceanogr. 2014;59:311-24.

58. Reid T, Chaganti SR, Droppo IG, Weisener CG. Novel insights into freshwater hydrocarbon-rich sediments using metatranscriptomics: opening the black box. Water Res. 2018;136:1-11.

59. Weber KA, Achenbach LA, Coates JD. Microorganisms pumping iron: anaerobic microbial iron oxidation and reduction. Nat Rev Microbiol. 2006;4:752-64.

60. Ward N, Larsen $\varnothing$, Sakwa J, Bruseth L, Khouri H, Durkin AS, et al. Genomic insights into methanotrophy: the complete genome sequence of Methylococcus capsulatus (Bath). PLoS Biol. 2004;2:1616-28.

61. Versantvoort W, Pol A, Jetten MSM, van Niftrik L, Reimann J, Kartal B, et al. Multiheme hydroxylamine oxidoreductases produce NO during ammonia oxidation in methanotrophs. Prot Natl Acad Sci USA. 2020;117:24459-63.

62. Richardson DJ, Berks BC, Russell DA, Spiro S, Taylor CJ. Functional, biochemical and genetic diversity of prokaryotic nitrate reductases. Cell Mol Life Sci. 2001;58:165-78.

63. Carere CR, McDonald B, Peach HA, Greening C, Gapes DJ, Collet C, et al. Hydrogen oxidation influences glycogen accumulation in a verrucomicrobial methanotroph. Front Microbiol. 2019;10:1873. 
64. Hanczár T, Csáki R, Bodrossy L, Murrell JC, Kovács KL. Detection and localization of two hydrogenases in Methylococcus capsulatus (Bath) and their potential role in methane metabolism. Arch Microbiol. 2002;177:167-72.

65. Shah NN, Hanna ML, Jackson KJ, Taylor RT. Batch cultivation of Methylosinus trichosporium OB3b. 4: production of hydrogen-driven soluble or particulate methane monooxygenase activity. Biotechnol Bioeng. 1995;45:229-38.

66. Mohammadi S, Pol A, van Alen TA, Jetten MSM, Op den Camp HJM. Methylacidiphilum fumariolicum SolV, a thermoacidophilic 'Knallgas' methanotroph with both an oxygen-sensitive and -insensitive hydrogenase. ISME J. 2017;11:945-58.

67. Carere CR, Hards K, Houghton KM, Power JF, McDonald B, Collet C, et al. Mixotrophy drives niche expansion of Verrucomicrobial methanotrophs. ISME J. 2017;11:2599-610.

68. Orata FD, Meier-Kolthoff JP, Sauvageau D, Stein LY. Phylogenomic analysis of the Gammaproteobacterial methanotrophs (Order Methylococcales) calls for the reclassification of members at the genus and species levels. Front Microbiol. 2018;9:3162.

69. Kucera J, Sedo O, Potesil D, Janiczek O, Zdrahal Z, Mandl M. Comparative proteomic analysis of sulfur-oxidizing Acidithiobacillus ferrooxidans CCM 4253 cultures having lost the ability to couple anaerobic elemental sulfur oxidation with ferric iron reduction. Res Microbiol. 2016;167:587-94.

70. Kucera J, Zeman J, Mandl M, Cerna H. Stoichiometry of bacterial anaerobic oxidation of elemental sulfur by ferric iron. Antonie van Leeuwenhoek. 2012;101:919-22.

71. He QX, Yu LP, Li JB, He D, Cai XX, Zhou SG. Electron shuttles enhance anaerobic oxidation of methane coupled to iron (III) reduction. Sci Total Environ. 2019;688:664-72.

72. Jing XX, Wu YC, Shi L, Peacock CL, Ashry NM, Gao CH, et al. Outer membrane ctype cytochromes OmcA and MtrC play distinct roles in enhancing the attachment of Shewanella oneidensis MR-1 cells to goethite. Appl Environ Microbiol. 2020;86:e01941-20.

73. Tanaka K, Vokoe S, Igarashi K, Takashino M, Ishikawa M, Hori K, et al. Extracellular electron transfer via outer membrane cytochromes in a methanotrophic bacterium Methylococcus capsulatus (Bath). Front Microbiol. 2018;9:2905.

74. Kamalanathan M, Dao LHT, Chaisutyakorna P, Gleadow R, Beardall J. Photosynthetic physiology of Scenedesmus sp (Chlorophyceae) under photoautotrophic and molasses-based heterotrophic and mixotrophic conditions. Phycologia. 2017;56:666-74.

75. Qu LR, Wang C, Bai E. Evaluation of the $180-\mathrm{H} 2 \mathrm{O}$ incubation method for measurement of soil microbial carbon use efficiency. Soil Biol Biochem. 2020;145:107802.
76. Kapiluto Y, Yakir D, Tans P, Berkowitz B. Experimental and numerical studies of the 180 exchange between $\mathrm{CO} 2$ and water in the atmosphere-soil invasion flux. Geochim Cosmochim Acta. 2007;71:2657-71.

77. Zeebe RE. Kinetic fractionation of carbon and oxygen isotopes during hydration of carbon dioxide. Geochim Cosmochim Acta. 2014;139:540-52.

\section{ACKNOWLEDGEMENTS}

This work was conducted under BLM permit (FF095556), and North Slope Borough permits (NSB 09-0478 and NSB 10-018). Any use of trade, firm, or product names is for descriptive purposes only and does not imply endorsement by the U.S. Government. This work was supported by funding from United States Department of Energy National Energy Technology Laboratory (Grant DE-NT000565) and National Natural Science Foundation of China with Grants No. 91851109 and 41671245 and Natural Science Foundation of Zhejiang province with Grant No. LZ20E080002. Support for the UAF molecular instrumentation in the Institute of Arctic Biology Genomics Core Laboratory was provided by an Institutional Development Award (IDeA) from the National Institute of General Medical Sciences of the National Institutes of Health under grant number 2P20GM103395. The findings and conclusions in this article are those of the authors and do not necessarily reflect the official views of the NIH.

\section{COMPETING INTERESTS}

The authors declare no competing interests.

\section{ADDITIONAL INFORMATION}

Supplementary information The online version contains supplementary material available at https://doi.org/10.1038/s41396-021-01049-y.

Correspondence and requests for materials should be addressed to R.H. or M.B.L.

Reprints and permission information is available at http://www.nature.com/ reprints

Publisher's note Springer Nature remains neutral with regard to jurisdictional claims in published maps and institutional affiliations. 